\title{
EMER DE VATTEL (1714-1767) E O DIREITO INTERNACIONAL CLÁSSICO
}

\author{
EMER DE VATTEL (1714-1767) AND THE CLASSIC INTERNATIONAL LAW
}

Paulo Borba Casella*

\begin{abstract}
Resumo:
A principal obra (1758) de Vattel se insere com destaque na fase 'clássica' do direito internacional, que marca profundamente a história da evolução da disciplina. A tal ponto, que muitos ainda parecem pensar e ver somente esse modelo 'clássico', como o único possível, para o direito internacional. Mas essa experiência, além de temporalmente circunscrita, como momento histórico, prepara e dá sustentação, para a ulterior evolução do direito internacional. Na fase seguinte, se configura o paradoxo de se perder a vocação de universalidade do direito internacional, na exata medida e proporção, em que ganha em desenvolvimentos conceituais e institucionais. Esse paradoxo ainda parece marcar o direito internacional, até os nossos tempos pós-modernos.

Palavras-chave: Emer de Vattel. Direito Internacional. Evolução histórica do Direito Internacional.
\end{abstract}

\begin{abstract}
:
Vattel's main work (1758) is paramount in the 'classical' age of the International Law, and left a deep mark in the evolution of this subject. To the extent that many scholars still seem to think and see only this 'classical' model as the only viable for International Law. This experience, however, not only is timely limited, as an historical moment, but also prepares and supports the subsequent evolution of the International Law. In later stages, appears the paradox of losing the call for universality in International Law, in the same measure and proportion that conceptual and institutional developments were added thereto. This paradox stills seems to mark International law, down to our post-modern times.
\end{abstract}

Keywords: Emer de Vattel. International Law. Historical evolution of the International Law.

Professor Titular de Direito Internacional Público da Faculdade de Direito da USP; presidente do IDIRI - Instituto de Direito Internacional e Relações Internacionais de São Paulo; Coordenador da Comissão de Publicação da Revista da FDUSP; Coordenador do CEPIM - Centro de Estudos sobre Proteção Internacional de Minorias da USP e do GEBRICS - Grupo de Estudos sobre os BRICS da USP; ministrou curso sobre Direito Internacional, História e Cultura, na Academia de Direito Internacional da Haia, em janeiro de 2020. 
É da maior importância para as Nações que o direito das gentes, base de sua própria tranqüilidade, seja respeitado universalmente. Se alguma Nação espezinhar abertamente esse direito, todas podem e devem insurgir-se contra ela e, ao reunirem suas forças para punir esse inimigo comum, elas estão cumprindo seus deveres para consigo mesmas e para com a sociedade humana, da qual são membros.

E. de Vattel, Direito das gentes (1758) ${ }^{1}$

Comparado com os seus predecessores, ou com os seus colegas mais conhecidos, VATTEL foi o primeiro a colocar conjunto mais preciso de normas, formando todo coerente e autônomo, apto a ser aplicado a uma comunidade internacional que não era hierarquizada e cuja base era a noção do estado soberano.

Benedict von Tscharner (2012, p. 73)

Vattel tinha plena consciência do caráter inovador e progressista dos trabalhos de Christian WOLFF, mas sem medir, ele mesmo, o alcance da mudança que implicava realmente o Jus gentium de WOLFF e mais ainda sua própria obra de 1758. Não recoloca ele GRÓCIO entre os primeiros que tiveram a intuição de um direito estritamente aplicável aos estados? Ele mesmo tinha assim, involuntariamente, suscitado essa interpretação errônea, sem se dar conta que se seus predecessores tinham legado o material teórico, permitindo o surgimento do direito internacional clássico, eles não o tinham, contudo, realizado. Assim, os que durante muito tempo nós consideramos como os pais do direito internacional, quer sejam GRÓCIO ou PUFENDORF, BARBEYRAC ou BURLAMAQUI, RACHEL ou TEXTOR, somente o são de maneira indireta ou secundária, quando essa mesma paternidade, longamente controvertida, pode ser reconhecida, sem contestação, segundo nosso entendimento, a WOLFF e depois a VATTEL.

Emmanuelle Jouannet (1998, p. 421) Emer de VATTEL e a emergência doutrinal do direito internacional clássico.

A escola de tradição grociana estaria no meio termo entre a escola filosófica de PUFENDORF e de seus sucessores e a escola histórica positiva, que no século XVIII ilustraram BYNKERSHOEK e MOSER. Mas, na realidade, WOLFF e seus discípulos apresentam ainda sua doutrina sob forma muito mais filosófica que positiva, e se eles se libertaram do

Emer de Vattel (2004, cap. XXIII, § 283, p. 180-181) do original Le droit des gens: principes de la loi naturelle, appliqués à la conduite et aux affaires des nations et des souverains. 
caráter abstrato e estéril da escola do direito natural puro, eles, contudo, não souberam se aproveitar dos elementos que lhes eram oferecidos pelas pesquisas históricas de Samuel RACHEL e de TEXTOR, e as coletâneas de tratados de LEIBNIZ e de DUMONT.

A obra de VATTEL não escapou desse defeito. Nela encontramos, sem dúvida, tendência manifesta e louvável a se aproximar das realidades do direito positivo e é melhor levá-lo em consideração, e os exemplos históricos, sobretudo, são numerosos, embora muitas vezes mal escolhidos e desigualmente distribuídos, mas a marca filosófica de WOLFF continua preponderante e a justaposição de dois elementos, a tal ponto inconciliáveis impede que o Direito das gentes tenha podido alcançar a perfeição que almejara o seu autor.

\section{A. MALLARMÉ, Emer de VATTEL $(1904)^{2}$}

Emer de Vattel nasceu em 25 de abril de 1714, em Bouvet, no então principado de Neuchâtel - que, a partir de 1707, integrava o reino da Prússia, e somente se tornou um dos cantões da Suíça em 1815. ${ }^{3}$ Embora se considerasse suíço, ou, pelo menos, essencialmente assim, por sua formação e espírito - como ele próprio afirmou - não se pode deixar de notar que, tecnicamente, Vattel era prussiano. E justamente por esse motivo esteve, durante algum tempo, em Berlim, procurando emprego junto à corte prussiana.

Vattel, contudo, fazia espécie de profissão de fé, em torno do seu lugar de nascimento, e no 'prefácio do autor' de sua principal obra (1758), assim se declarava: "nasci num país cuja liberdade é a alma, o tesouro, e a lei fundamental; posso ser ainda, por meu nascimento, amigo de todas as Nações". ${ }^{4}$

2 André Mallarmé (1904, p. 482-483), aduzia, ainda na mesma passagem: "VATTEL reste cependant illustre et son œuvre mérite d'être étudiée, car, s'il n'a pas su se dégager suffisamment de la doctrine de son maître, du moins a-t-il eu le grand mérite de l'avoir exposé en une forme limpide et sur un plan commode qui ont contribué à répandre dans les sphères officielles et dans le public les principes du droit international".

3 A respeito, ver Alexandre Dafflon (2009, p. 82): "L'épreuve de la guerre de Dix ans, si elle n'aboutit pas à la reconnaissance de Neuchâtel comme membre du Corps helvétique, n'en contribua pas moins à un renforcement de facto de son statut d'allié de Berne bénéficiant de la neutralité des Suisses. [...] Le statut ambigu de la principauté n'en demeurait pas moins et les tensions vives qui secoueraient le second XVII ${ }^{e}$ siècle - difficultés successorales, immixtions constantes d'une France conquérante dans les affaires intérieures - le prouveraient jusqu'à la 'grande affaire' de 1707. Et, en dépit des évolutions liées à l'histoire de la Confédération et de l'Europe de 1648 à 1815, les questions posées par HENRI II ne cessèrent pas de se poser aux hommes d'état et à l'opinion publique - nouvel acteur apparu au XVIII siècle - au cours du long siècle et demi qui devait mener à la naissance d'un canton de Neuchâtel en 1814".

4 Vattel (2004, 'Prefácio do autor', p. LXXXV) terminava a passagem desejando que os leitores encontrassem em sua obra "o homem honesto e o cidadão". 
Como outros juristas e pensadores desses tempos, Vattel foi filho de pastor protestante. Estudou, primeiro, teologia em Basileia, antes de passar para a filosofia. Foi para Genebra, em 1733, para aperfeiçoar os seus estudos de teologia e de metafísica, mas os seus gostos o levaram para a filosofia pura, e a leitura das obras de Leibniz e de Wolff teria impacto decisivo sobre a sua vocação. ${ }^{5}$

Vattel seguiu à procura de emprego, em 1741, para Berlim, e em 1743, para Dresden. Depois de permanecer algum tempo a Neuchâtel, segue novamente para Dresden, de onde, em 1746, foi nomeado e seguiu para exercer as funções de Conselheiro da legação e ministro da Saxônia, junto à República de Berna. Durante os nove anos que duraram essas funções, Vattel escreveu a maior parte de suas obras. ${ }^{6}$

Nessa época, a Alemanha vivia os estragos da guerra dos sete anos. Em 1758, Vattel foi chamado de volta a Dresden, por Augusto III, príncipe-eleitor da Saxônia e rei da Polônia, onde Vattel passou a exercer as funções de Conselheiro secreto (Geheimten Rath), com a considerável e bem remunerada incumbência de dirigir as relações exteriores do reino.

5 Em 1741 e 1742, VATTEL publica a sua defesa do sistema de Leibniz, Défense du système Leibnitien contre les objections et les imputations de M. de Crousaz, etc., publicada em Leiden, e dedicada a FREDERICO II da Prússia. Esta obra de polêmica atraiu a atenção da opinião pública, pela sutil discussão a respeito da liberdade da vontade humana. VATTEL tinha como propósito reabilitar o sistema de LEIBNIZ, e especialmente a sua teoria da harmonia preestabelecida, que CROUSAZ, filósofo e matemático suíço pretendera substituir pela vontade divina. A respeito da contribuição de Leibniz para o direito internacional ver o Direito internacional no tempo clássico (CASELLA, 2015, item 22.1, 'o direito segundo LEIBNIZ', p. 657-704).

6 Como observava André Mallarmé (1904, p. 485), não tendo obrigação de residência permanente em Berna, VATTEL podia passar temporadas em Neuchâtel com a sua família, e "consagrando às letras o tempo livre que lhe deixava a sua missão", publicou, sob diversos títulos, vários volumes de poesia, de filosofia, de moral e de literatura, mas dedicou-se, sobretudo, à sua obra Droit des gens, originalmente publicada em 1758 . Dentre as publicações de VATTEL: Pièces diverses avec quelques lettres de morale et d'amusement (Paris, 1746); Le loisir philosophique, on pièces diverses de philosophie, de morale et d'amusement (Genebra, 1747, como segunda edição, com alguns acréscimos da publicação do ano anterior; e mais outra edição foi impressa, no mesmo ano de 1747, em Dresden), dentre os textos contidos no volume, o Projet pour la composition d'un elixir des livres, avec diverses lettres à ce sujet, foi traduzido para o alemão, e publicado na Bibliothek für schönen Wissenschaften; Poliergie ou mélanges de littérature et de poésie (Amsterdam, 1757); Amusements de littérature, de morale ou de politique (La Haye, 1765); Guerre littéraire ou choix de quelques polémiques (1759); Mélanges de littérature, de morale et de politique (Neuchâtel, 1760) e Questions de droit naturel et observations sur sur le traité du droit de la nature par M. le baron de WOLFF (Berna, 1762; depois publicadas em Paris, 1763). 
Nesse mesmo ano, Vattel ainda publicou a sua obra sobre o Direito das gentes (1758). ${ }^{7}$ Obra que encontrou enorme repercussão. ${ }^{8}$ A ponto de deixar em plano secundário todas as demais publicações de Vattel. ${ }^{9}$

A obra de Vattel teve extenso e duradouro uso, não somente no ambiente acadêmico. Eisso se deu, além da Europa, também deste lado do Atlântico, desde a Faculdade de Direito de São Paulo, ${ }^{10}$ como também em várias universidades estadunidenses. ${ }^{11}$ Também foi adotado o livro de Vattel pelas chancelarias diplomáticas de vários países, como manual para o estudo e a prática do direito e das relações internacionais.

Exemplo dessa extensa repercussão, Edmund Burke (1729-1797), ${ }^{12}$ citou Vattel, como autoridade em direito internacional, na Câmara dos Lordes, no julgamento do caso Warren Hastings (1786). ${ }^{13}$ É interessante o caso, para mostrar como um dirigente indiano - o rajá de Benares -, agindo com base em seus próprios princípios consuetudinários de relações internacionais, encontrou respaldo em princípios similares, deduzido do direito das gentes, tal como evoluíra na prática dos estados europeus, e fora

$7 \quad$ Título original: Le droit des gens, ou principes de la loi naturelle appliqués à la conduite et aux affaires des Nations et des Souverains par Mr. de VATTEL (II tomes, Neuchâtel: Journal Helvétique, 1758), mas também se encontram edições a Londres, como também a Leide 1758 (tom. III, ibid., 1758). A seguir foi publicada a edição de Neuchâtel de 1773 («nouvelle édition augmentée» Neuchâtel II. tom. 1773) - esta edição contém relato da vida e anotações do autor; a seguir, a edição de Amsterdam («nouvelle édition augmentée, revue et corrigée, avec quelques remarques de l'Éditeur» Amsterdam, II. tom. 1775); e ainda a nova edição de Neuchâtel de 1777 («nouvelle édition» Neuchâtel IIII. tom. 1777) - esta edição contém relato da vida do autor, mas omite as observações e acréscimos.

8 Emer de VATTEL (2004), bem como tb. a tradução para o inglês da obra de E. de VATTEL, The law of nations or the principles of natural law: applied to the conduct and to the affairs of nations and of sovereigns (translation of the edition of 1758 by Charles G. Fenwick, with an intr. by Albert de Lapradelle, Washington: Carnegie Institution, 1916, special edition privately printed for the members of the Legal Classics Library, 1993).

9 Nota Francesco Mancuso (2004, p. 201), em capítulo sobre Emmerich de VATTEL: "Homo unius libri: assim, com uma expressão que seria redutiva se não salientasse a unicidade de sua obra prima, poderia ser definido E. de VATTEL (1714-1767). As obras menores que, de fato, até foram numerosas e que são essenciais para a compreensão de seu pensamento, devem ser consideradas momentos preparatórios ou mesmo apêndices da obra principal: Le droit des gens, ou principes de la loi naturelle, appliqués à la conduite et aux affaires des nations et des souverains (1758)".

10 Como mencionado, assim ocorreu na Faculdade de Direito de São Paulo, hoje integrada à Universidade de São Paulo. Desse modo, Wolff, retomado e revisitado por Vattel, foi a base do ensino do direito das gentes, durante considerável tempo, nas "Arcadas". A respeito, ver a aula inaugural de 16 de fevereiro de 2009. (CASELLA, 2009, v. 104, p. 931-966).

11 E. Jouannet (2012, p. 1.118), Emer de Vattel (1714-1767): "From its first publication, VATTEL's Law of Nations attracted widespread interest. Numerous editions and translations followed, and its influence reached across the Channel to England and from there to the United States, where the book soon became a reference manual in American universities. From the $18^{\text {th }}$ to the beginning of the $20^{\text {th }}$ century, his authority on the subject of international law remained unrivalled".

12 Edmund Burke (1999, p. 388-406), Speeches on the impeachment of Warren Hastings.

13 Edmund Burke, The defence of Warren Hastings at the Bar of the House of Commons (London, 1786; in Burke, Works, vols. IV e XIII, 1821; tb. Speeches at the trial of W. Hastings, ed. by E. A. Bond, 1859). 
apresentado na obra de Vattel. ${ }^{14}$ Para citar a frase crucial de Burke: "existe somente uma lei no mundo, nomeadamente a lei que governa todas as leis ... a lei da humanidade, da justiça, da equidade, o direito natural e das gentes". ${ }^{15}$

Vattel tinha antes publicado alguns textos sobre direito internacional, ${ }^{16} \mathrm{e}$ em 1762, ainda publicou o opúsculo filosófico sobre "questões de direito natural", ou Questions de droit naturel, destinado a esclarecer alguns aspectos da doutrina de Christian Wolff. ${ }^{17}$ Assim, ainda no último trabalho jurídico publicado, Vattel continuava a se reportar à obra do seu mestre.

Em 1766, obtém licença para tratamento médico e permanece durante algum tempo em Neuchâtel. ${ }^{18}$ Vattel faleceu, aos 53 anos, em 28 de dezembro de $1767 .{ }^{19}$ Deixou uma jovem viúva, com quem se casara em 1764, e um filho, Charles Adolphe

14 C. H. Alexandrowicz (1960, v. 100, p. 203-322), em curso na Haia, em pouco mais de uma centena de páginas 39 vezes cita VATTEL. A respeito de Edmund BURKE utilizar Vattel como autoridade em matéria de direito internacional, em seus discursos sobre o caso, na Câmara dos Lordes, comentava Alexandrowicz (1960, v. 100, p. 216-217): "It is interesting to note that when Warren HASTINGS, governor general of the English East India Company in the second half of the XVIII ${ }^{\text {th }}$ century, interfered with the generally recognized rights of one of the subordinate rulers (the raja of Benares) his action was severely criticised at Westminster. He was impeached before Parliament on this and other counts relating to his governorship in India and BURKE, one of the greatest English political writers, arguing against him, defended the rights of raja of Benares by arguments drawn from VATTEL's Droit des gens particularly from volume I, chapter 16 , relating to treaties of protection. VATTEL refers to the duties of a superior or protecting state vis-à-vis a dependent state and emphasises that should the superior 'assume greater authority over the weaker one than the treaty of protection or submission allows, the latter may consider the treaty as broken and provide for its safety according to its discretion",.

15 To quote Burke's crucial statement: «There is but one law in the world, namely the law which governs all law; the law of humanity, justice, equity, the law of nature and nations».

16 Vattel, Essai sur le fondement du droit naturel et sur le premier principe de l'obligation où se trouvent les hommes d'en observer les lois seguido da Dissertation sur cette question: la loi naturelle peut-elle porter la société à la perfection sans le secours des lois politiques? que constituem espécie de trabalho preparatório para o Direito das gentes (1758, 'Preliminares', § 6), porquanto Vattel considera que este originalmente não passa de «le droit de la nature appliqué aux nations».

17 André Mallarmé (1904, p. 487) observava a respeito: “Ces Observations qui n'avaient pas d'abord été destinées au public, parurent à Berne, au commencement de 1762, puis à Paris, en 1763. VATTEL, en lisant l'ouvrage de WOLFF, s'était aperçu de quelques écarts dans la méthode et d'inexactitudes dans les démonstrations; il voulut rectifier ces erreurs et réunit un certain nombre de propositions qu'il discute en peu de mots. Ce petit ouvrage est comme un commentaire de l'œuvre de WOLFF".

18 André Mallarmé (1904, p. 486) considera relevante destacar três aspectos da biografia de Vattel: o gosto pela filosofia, e o fato de ter estudado aprofundadamente o sistema filosófico de Leibniz; o fato de ser diplomata e conhecer o gosto do público culto das cortes europeias; e o fato de ter permanecido cidadão suíço e ter conservado a sua independência, e concluía: "Ces différentes particularités nous permettront d'expliquer plusieurs caractères de son œuvre: philosophe, VATTEL la bâtira sur les bases du système qu'il a préconisé; diplomate, il saura l'écrire en un style élégant et dans la forme qui devait plaire aux personnes auxquelles il s'adressait; citoyen suisse, il conservera, malgré ses fonctions, l'amour profond de l'indépendance et de la liberte dont jouissait sa patrie".

19 Observava André Mallarmé (1904, p. 483): “Il n’y eut pas, dans la vie de VATTEL, d'évévenements fortuits et décisifs, susceptibles, comme pour GROTIUS ou PUFENDORF, d'influer sur ses conceptions ou de provoquer l'éclosion de ses œuvres; mais les traits généraux de sa biographie permettent d'expliquer certaines de ses idées et la forme sous laquelle il les a présentées au public". 
Maurice Vattel (1765-1827), que além de exercer diversas funções, se ocupou sobretudo de literatura.

O internacionalista Emer de Vattel, inscreve-se na assim chamada 'tradição grociana' ${ }^{20}$ Em movimento que configura certa oposição ao assim chamado "movimento pufendorfiano", por se considerar que este acentuaria excessivamente o papel do direito natural no direito internacional. ${ }^{21}$

Como se situa Vattel, em relação aos seus predecessores? Este não deixa de assinalar suas diferenças em relação ao "célebre Grócio", e se manifesta de maneira crítica em relação à obra de seu ilustre antecessor:

Parece, por diferentes passagens de sua excelente obra, que esse grande homem entreviu a verdade. Mas, como ele decifrava, por assim dizer, uma importante matéria, muito negligenciada antes dele, não é surpreendente que, tendo o espírito sobrecarregado por quantidade imensa de objetos e de citações, que entravam em seu plano, nem sempre tinha ele chegado a idéias distintas, tão necessárias, contudo, nas ciências. (VATTEL, 2004, 'Prefácio do autor', p. LXXIII).

O que dá lugar à diferença essencial entre ambos, segundo reportava Vattel:

Persuadido [Grócio] de que as Nações ou as potências soberanas estão submetidas à autoridade da lei natural, cujo respeito ele tão freqüentemente recomenda, esse sábio reconhecia, no fundo, um direito das gentes natural (o qual denomina por vezes de direito das gentes interno); e talvez ele não parecerá diferir de nós senão nos termos. Mas já observamos que, para formar esse direito natural, não basta apenas aplicar às Nações o que a lei natural decide

$20 \quad$ A respeito de Grócio e sua contribuição para o direito internacional, ver Casella (2014, cap. XVIII, p. 309587). Apontava André Mallarmé, Emer de Vattel (1714-1767) (1904, p. 481) a sua interpretação a respeito da obra e do papel de Vattel, na evolução histórica do direito internacional: "VATTEL appartient à cette école de jurisconsultes que l'on a appelée la tradition grotienne, et qui, à la fin du XVII et début du XVIII ${ }^{\mathrm{e}}$ vint réagir contre la théorie du droit naturel pur enseigné par PUFENDORF". Seria, segundo Mallarmé a expressão de corrente que se confronta com a visão de Pufendorf - esta considerada excessivamente naturalista - e, assim, com Wolff, com Vattel e com Zouch se faria retorno (ainda que parcial) à concepção grociana do direito internacional: "Il admet sans doute le droit naturel comme une source directe du droit des gens, mais le considère seulement comme une source subsidiaire qui n'est obligatoire qu'en l'absence des lois positives ou à leur défaut". O que não se coaduna com os vários trechos citados, da própria obra (1758), e nos quais Vattel expõe o caráter fundamental do que chama de "direito das gentes necessário". Positivista seria, antes, a interpretação de Mallarmé (1904) do que propriamente a concepção central de Vattel (1758).

21 E. Jouannet (1998, p. 25): "Très brièvement résumé, on peut dire que le mouvement pufendorfien ne reconnaît pas l'existence d'un droit des gens positif, que, sur les traces de SUAREZ, GROTIUS avait admis, pour sa part, dans le Jus bellum ac pacis; si bien que l'on peut d'emblée diviser l'école du droit naturel en deux courants distincts, prenant leurs sources dans les doctrines opposées das deux grands inaugurateurs du mouvement jusnaturaliste, qui penchent l'un vers une solution jusnaturaliste, l'autre vers une doctrine positive du droit des gens". 
em relação aos particulares. (VATTEL, 2004, 'Prefácio do autor', p. LXXIII-LXXIV).

Em relação a Hobbes e Pufendorf, igualmente, Vattel não deixava de assinalar as suas diferenças:

Hobbes, na obra em que se reconhece habilidade, malgrado os seus paradoxos e princípios detestáveis; Hobbes, digo, é segundo creio, o primeiro a ter uma idéia distinta mas ainda imperfeita do direito das gentes. Ele divide a lei natural em lei natural do homem e lei natural dos Estados. Esta última, segundo ele, é o que se denomina de ordinário direito das gentes. [...] Este autor bem observou que o direito das gentes é o direito natural aplicado aos Estados ou às Nações. [...] Ele se enganou quando acreditou que o direito natural não sofria nenhuma modificação necessária nessa aplicação; donde ter ele concluído que os princípios do direito natural e os do direito das gentes são precisamente os mesmos. (VATTEL, 2004, 'Prefácio do autor', p. LXXIV-LXXV).

Pufendorf declara subscrever completamente essa opinião de Hobbes. Tampouco tratou separadamente do direito das gentes, confundindo-o em toda parte com o direito natural propriamente dito.

Pode ser pouco menos crítico em relação a Barbeyrac, mas também formula Vattel suas críticas à concepção do direito internacional na obra deste - e também em relação às traduções que Barbeyrac fez, para o francês, das obras de Grócio e de Pufendorf:

Barbeyrac, tradutor e comentarista de Grócio e de Pufendorf, muito se aproximou da idéia justa do direito das gentes. [...] $\mathrm{O}$ autor que acabamos de ouvir compreendeu bem que as regras e as decisões do direito natural não podem aplicar-se pura e simplesmente aos Estados soberanos, e que devem necessariamente sofrer algumas modificações, segundo a natureza dos novos sujeitos aos quais elas se aplicam. Mas não parece que ele tenha visto toda a extensão dessa idéia, porquanto se afigura não aprovar que se trate o direito das gentes separadamente do direito natural dos particulares. (VATTEL, 2004, 'Prefácio do autor', p. LXXV).

Não poderia Vattel deixar de apontar os estreitos e fortes vínculos com o mestre. Ele declara-se discípulo de Wolff, desde as 'preliminares' de seu livro (1758, ed. 2004): "seriam necessárias mais profundas meditações e vistas mais extensas para conceber a idéia de um sistema de direito das gentes natural que fosse assim como a fé dos soberanos e das nações, para sentir a utilidade de semelhante obra e sobretudo para iniciar-lhe a execução".

A glória disso - afirmava Vattel - foi reservada ao barão de Wolff. Este grande filósofo viu que a aplicação do direito natural às nações enquanto corpo, ou aos 
estados, modificada pela natureza dos sujeitos, não pode fazer-se com precisão, com nitidez e com solidez, senão com a ajuda dos princípios gerais que devem regulamentá-la; que é apenas por meio desses princípios que se pode mostrar evidentemente como, em virtude do próprio direito natural, as decisões desse direito, em relação aos particulares devem ser transformadas e modificadas quando aplicadas aos estados ou sociedades políticas, e formarem assim um direito das gentes natural e necessário: donde ter ele concluído ser conveniente constituir um sistema particular desse direito das gentes; e ele o executou com felicidade. (VATTEL, 2004, 'Prefácio do autor', p. LXXVI-LXXVII). Mas Vattel, ao mesmo tempo em que faz extensos e substanciais 'empréstimos' da obra de Wolff, ${ }^{22}$ não deixa de marcar as distâncias entre ambos: ${ }^{23}$

Convencido eu próprio da utilidade de semelhante obra, esperava com impaciência a de Wolff e, desde que ela surgiu, propus-me propiciar ao maior número de leitores o conhecimento das idéias luminosas que ela apresenta. O tratado do filósofo de Halle sobre o direito das gentes é dependente de todos os do mesmo autor sobre a filosofia e o direito natural. Para lê-lo e entendê-lo é preciso ter estudado os dezesseis ou dezessete volumes que o precedem. Aliás, ele está escrito no método e mesmo na forma das obras de geometria: tantos obstáculos que o tornam quase inútil às pessoas nas quais o conhecimento e o gosto dos verdadeiros princípios do direito das gentes são mais importantes e mais

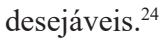

Antes de Vattel, também Wolff se declarara discípulo de Leibniz. ${ }^{25}$ De maneira menos tortuosa e insidiosa. ${ }^{26}$ Desse modo se pode apontar encadeamento adicional

22 Cf. se examina em P. B. Casella (2015, capítulo XXII, p. 621-719) a respeito de Christian Wolff (16791754).

23 Vattel (2004, 'Prefácio do autor', p. LXXVII-LXXVIII) aduzia: "Pensei, de início, que me bastaria separar por assim dizer esse tratado do sistema integral, tornando-o independente de tudo o que precede a Wolff, e revesti-lo de forma mais agradável, mais adequada a permitir-lhe acesso ao mundo civilizado. Fiz algumas tentativas a respeito; mas logo reconheci que se desejasse obter leitores aos quais tivesse o propósito de escrever, e produzir algum fruto, devia fazer obra muito diferente daquela que tinha sob os olhos, e trabalhar de novo".

24 Vattel (2004, 'Prefácio do autor', p. LXXVIII) apesar das críticas - nem sempre leais - não deixava de reconhecer quanto tomou 'emprestado' da obra de WOLFF: "O método que Wolff seguiu expandiu a sequidão em seu livro e o tornou incompleto sob muitos aspectos. As matérias nele estão dispersas de maneira cansativa para a atenção e, como o autor tinha tratado do direito público universal em seu direito da natureza, ele se contenta freqüentemente em a ele referir-se, quando, no direito das gentes, cuida dos deveres de uma Nação para consigo mesma".

25 A respeito da vida e da obra de Christian Wolff (1679-1754), e de sua relevante contribuição para o direito internacional 'clássico', ver o Direito internacional no tempo clássico (CASELLA, 2015, capítulo XXII, p. 621-719). A respeito da influência de Leibniz sobre a obra de Wolff e sobre temas jurídicos tratados por Leibniz ver, especificamente, o item 22.1, 'o direito segundo LEIBNIZ' (CASELLA, 2015, p. 657-704).

26 E. de Vattel (2004, 'Prefácio do autor', p. LXXIX): "Não reconheço outra sociedade natural entre as Nações 
de Leibniz com o desenvolvimento histórico do direito internacional 'clássico', porquanto, além de outros méritos, teria assim o grande filósofo influenciado, ${ }^{27}$ decisivamente Wolff e Vattel, ambos expoentes do direito das gentes de meados do século XVIII. Apesar da importância menor de sua atividade relacionada ao direito dos tratados, em relação ao vasto e variado conjunto da obra filosófica, legada por Leibniz, fez 'escola' também em nosso campo, ao influenciar tanto Wolff diretamente, como através deste, Vattel.

Ao iniciar o exame do direito internacional - que ele ainda chamava 'direito das gentes' - Vattel permanece na zona fronteiriça entre concepções 'medievais' e 'modernas' deste, rumo ao que viria a ser a concepção 'clássica', ${ }^{28}$ que prepara o caminho para a sua nova configuração, no tempo do 'iluminismo': "o direito das gentes, esta matéria tão nobre e tão importante, não foi versado até aqui com todo o cuidado que merece. Também a maioria dos homens não tem dele senão uma noção vaga, muito incompleta, mesmo falsa com frequência". ${ }^{29}$

A concepção de Vattel a respeito da disciplina, se compreende quando declarava existir "direito das gentes necessário" ao lado de "direito das gentes voluntário":

Existe certamente um direito das gentes natural, porquanto a lei da natureza não obriga menos os Estados, os homens unidos em sociedade política, quanto obriga os particulares. Mas, para conhecer exatamente esse direito, não basta saber o que a lei da natureza prescreve aos indivíduos humanos. A aplicação de uma regra a sujeitos diversos não pode fazer-se senão de maneira conveniente à natureza de cada sujeito. Daí resulta que o direito das gentes natural é uma ciência particular, a qual consiste numa aplicação justa e meditada da lei natural aos negócios e à conduta das nações ou dos soberanos. Todos esses tratados, nos quais o direito das gentes está envolvido e confundido com o direito natural ordinário, são pois insuficientes para dar uma idéia distinta, um sólido conhecimento da lei sagrada das Nações. ${ }^{30}$

Vattel se posiciona claramente na perspectiva de que o direito internacional decorre da prática dos estados, ao ponderar: "de nada adiantar como princípio o que não

senão aquela mesma que a natureza estabeleceu entre todos os homens".

27 Ver o Direito internacional no tempo clássico (2015, esp. item 22.1, 'direito segundo LEIBNIZ', p. 657704).

28 O que ilustra o peso e o papel desempenhado pela "escola do direito natural". Ver, no Direito internacional no tempo clássico (CASELLA, 2015, capítulo XXIII, p. 721-742) sobre Jean-Jacques Burlamaqui (16941748), que lecionou em Genebra, onde, dentre outros, foi professor de Vattel.

29 Vattel (2004, 'Prefácio do autor', p. LXXI), prosseguia: “Grande parte dos escritores e autores, embora célebres, não compreende, sob o nome de direito das gentes, senão determinados princípios, determinados atos recebidos entre as nações e para elas tornados obrigatórios pelo fato de neles consentirem".

30 Vattel (2004, 'Prefácio do autor', p. LXXI-LXXVII). 
seja facilmente admitido por toda pessoa razoável". Isso se vê já no 'prefácio do autor', quando Vattel expunha: "algumas vezes a prática das nações está de acordo com os princípios". Sintomaticamente, ressalvava, ‘algumas vezes’! E prosseguia:

O direito das gentes é a lei dos soberanos. É principalmente para eles e para os seus ministros que se deve escrevê-lo. Ele interessa verdadeiramente a todos os homens e o estudo de seus princípios convém, em país livre, a todos os cidadãos; mas importaria pouco ensiná-lo apenas aos particulares, que não são chamados aos conselhos das Nações e que não lhes determinam os procedimentos. Se os dirigentes dos povos, se todos aqueles empregados nos negócios públicos, se dignarem a fazer estudo sério de uma ciência que deveria ser a sua lei e a sua bússola, quantos frutos não se poderia esperar de um bom tratado do direito das gentes! Verificam-se todos os dias aqueles oriundos de um bom corpo de leis, na sociedade civil: o direito das gentes está tanto acima do direito civil em sua importância, quanto os procedimentos das Nações e dos soberanos ultrapassam, em suas conseqüências, os dos particulares. ${ }^{31}$

Convém tentar estabelecer claramente a distinção entre ambos os campos do direito: o que seja 'direito natural' e o que seja especificamente 'direito das gentes' não fica muito claro em Vattel. Este, contudo, afirma ser necessária essa distinção, para situar o conteúdo e os desdobramentos deste nosso ramo do direito: "os romanos confundiram frequentemente o direito das gentes com o direito da natureza, chamando direito das gentes (jus gentium) o direito natural, enquanto reconhecido e adotado geralmente por todas as nações civilizadas". ${ }^{32}$

Depois de referir as distinções feitas nas Institutas de Justiniano entre direito natural, direito das gentes e direito civil, afirmava Vattel:

O imperador parece aproximar-se bastante do sentido que hoje damos a esse termo. O direito das gentes, diz ele, é comum a todo o gênero humano. As atividades dos homens e suas necessidades conduziram todas as Nações a determinarem certas regras de direito. Pois as guerras surgiram e produziram cativeiros e servidões, os quais são contrários ao direito natural; porque originariamente, $e$ por direito natural, todos os homens nascem livres. ${ }^{33}$

\footnotetext{
31 Vattel (2004, 'Prefácio do autor', p. LXXXIII) aduzia: "Uma funesta experiência não prova senão quando em demasia quão poucos são aqueles que, à testa dos negócios, se preocupam com o direito de que esperam receber alguma vantagem".

32 Vattel (2004, 'Prefácio do autor', p. LXXI), citava CÍCERO, De officiis - Livro III, cap. 5): “Neque vero hoc solum natura, id est, jure gentium".

33 Vattel (2004, 'Prefácio do autor', p. LXXII), citava as Institutas, livro I, tít. II, § 1: “Jus autem gentium
} 
Vattel logo adiante completava, com razão ou sem ela, ainda reportandose a Justiniano: "ele acrescenta que quase todos os contratos, os de venda e compra, de locação, de sociedade, de depósito e uma infinidade de outros devem a sua origem a esse direito das gentes". Esse acréscimo indicaria que o pensamento de Justiniano é apenas que, segundo o estado e as conjecturas em que os homens se têm encontrado, a reta razão lhes ditou certos princípios de direito, tão fundados na natureza das cousas que são reconhecidos e admitidos em toda parte. E afirma Vattel: "não é apenas nisso que o direito natural convém a todos os homens":

\begin{abstract}
Entretanto, esses mesmos romanos reconheciam uma lei que obriga as Nações mutuamente e relacionavam com essa lei o direito das embaixadas. Eles também tinham o seu direito fecial, o qual não era outra coisa senão o direito das gentes referente aos tratados públicos e, em particular, à guerra. Os feciais (feciales) eram os intérpretes, os guardiões, e de algum modo os sacerdotes da fé pública.

Os modernos concordam geralmente em reservar o nome de direito das gentes ao direito que deve reinar entre as nações ou estados soberanos. Eles não diferem senão na ideia que tem sobre a origem desse direito e de seus fundamentos. ${ }^{34}$
\end{abstract}

O respeito de Vattel pela prática dos estados talvez seja uma das chaves para se compreender a ampla repercussão e o sucesso da obra: "propus-me manter religiosamente o respeito devido às nações e às potências soberanas". ${ }^{35} \mathrm{O}$ que seria o dado central e paradigmático da configuração do assim chamado 'direito internacional do tempo do iluminismo'.

No mesmo sentido, a ponderação de Emmanuelle Jouannet, como reflexo de movimento doutrinal em plena evolução, e transposição bem-sucedida, para o nível dos estados, como o diz muito claramente o próprio Vattel, da moral individual dos jusnaturalistas, seu Direito das gentes é, assim, um código geral de boa conduta dos estados entre eles, e no interior de cada um (chez eux), ao mesmo tempo em que é também uma obra especificamente destinada a tratar das relações internacionais. ${ }^{36}$

omnium humano generi commune est; nam usu exigente et humanis necessitatibus, gentes humanae jura quaedam sibi constituerunt. Bella et enim orta sunt et captivitates sequutae, et servitutes, quae sunt naturali juri contrariae. Jure enim naturali omnes homines ab initio liberi nascebantur".

34 Vattel (2004, 'Prefácio do autor', p. LXXII-LXXIII) completava o raciocínio: “O célebre GRÓCIO entende por direito das gentes um direito estabelecido pelo consentimento comum dos homens e ele assim o distingue do direito natural".

35 Vattel (2004, 'Prefácio do autor', p. LXXXIV-LXXXV).

36 E. Jouannet (1998, 'conclusion', p. 419): "Reflet de tout un mouvement doctrinal en pleine évolution, et transposition réussie au niveau des états, comme le dit très nettement VATTEL lui-même, de la morale individuelle des jusnaturalistes, son Droit des gens est donc un code général de bonne conduite des états entre eux, et chez eux, tout en étant aussi un ouvrage spécifiquement destiné à traiter des relations 
Existe e permanece ambiguidade essencial na obra de Vattel: este não adota a prática dos estados de maneira indistinta, porquanto sustentava: "impus-me uma lei ainda mais inviolável: a de respeitar a verdade e o interesse do gênero humano". ${ }^{37}$ Faltou somente explicar qual dos dois princípios norteadores deveria prevalecer em caso de conflito, a respeito de questões concretas. Essa ambiguidade permanece eixo central de indagação em torno do direito internacional até os nossos tempos pós-modernos.

Essa mesma ambiguidade transparece, por exemplo, quando Vattel situa a 'arbitragem', designando-a como: "meio muito razoável e muito conforme à lei natural, para solucionar qualquer controvérsia que não diga respeito à salvação da nação". ${ }^{38} \mathrm{Ou}$ seja, esta é, segundo ele, 'razoável' e 'conforme à lei natural' - mas as situações, nas quais pode ser aplicada a arbitragem, tem como limite que não sejam questões essenciais do interesse nacional e da prática do estado.

Notava Vattel: "quando os soberanos não podem pessoalmente solucionar as suas controvérsias, contudo, desejam manter ou restabelecer a paz, por vezes confiam a solução de tais controvérsias a árbitros, escolhidos por mútuo consentimento". 39 Asseverava que "tendo sido celebrada a convenção arbitral, as partes se comprometem a cumprir a decisão dos árbitros: que se obrigaram a tanto, e que a fé dos tratados precisa ser observada". 40

Situava, assim, Vattel (1758) a arbitragem como 'instituto razoável' e 'conforme à lei natural', mas o expunha com algumas reservas, em decorrência da prática dos estados. Compare-se a opinião de von Martens (1788, ed. 1821), ${ }^{41}$ a respeito da arbitragem, fazendo algumas restrições, ainda que de maneira distinta de Vattel. Para von Martens,

essa medida, muito utilizada em todo o curso da Idade Média, não foi inteiramente abandonada em nossos dias, mas os exemplos de arbitragens oferecidas e aceitas se tornaram mais e mais raros, pela experiência dos inconvenientes que parecem ser quase inseparáveis desse meio, ordinariamente insuficiente, sobretudo pela falta de um poder executivo. ${ }^{42}$

\footnotetext{
internationales".

37 Vattel (2004, 'Prefácio do autor', p. LXXXIV-LXXXV) prosseguia: “Tomaria o partido do silêncio se não pudesse seguir, em meus escritos, a as luzes de minha consciência. Mas nada segura a minha pena e não sou capaz de prostituí-la com a lisonja".

38 Vattel (1758, livre II, ch. XVIII, § 329): "L'arbitrage est un moyen très raisonnable et très conforme à la loi naturelle, pour terminer tout différend qui n'intéresse pas directement le salut de la nation".

39 Vattel (1758, livre II, ch. XVIII, § 329).

$40 \quad$ Vattel (1758, livre II, ch. XVIII, § 329).

41 Georg Friedrich von Martens (1821). A respeito de Martens, ver Casella, Direito internacional no tempo do Iluminismo (em preparação, cap. XXV).

42 Georg Friedrich von Martens (1821, p. 318) a respeito da arbitragem, no seu Précis du droit des gens moderne de l'Europe: "Cette mesure, très usitée dans tout le cours du moyen age, n'a pas été entièrement
} 
Sintomaticamente, quando von Martens discorre a respeito da arbitragem, ele reporta exemplos sobretudo do início do século XVIII.

Comenta C. Roelofsen (2012) 43 "no século XVIII, a ideia de arbitragem gozava de certa popularidade, mas a sua prática efetiva estava em declínio". Como indício de não ter havido 'eclipse total' da arbitragem, mencionava ser bastante reduzido o número de casos de arbitragem, reportados na prática de tratados, a partir de 1730.44

A impressão de inconsistência entre o fundo e a forma, entre o conteúdo e a manifestação desse direito das gentes em relação ao direito natural pode ser apontada. E por isso se justificou reportar o entendimento de Vattel sobre as origens romanas da disciplina, e a linha divisória entre o direito fecial e o jus gentium. ${ }^{45}$

O primeiro, o direito das gentes necessário, como declara Vattel, seria imutável e eterno: “as nações não podem mudar o direito das gentes necessário nem se eximir da obrigação que ele lhes impõe". ${ }^{46}$ Exemplifica e situa as linhas mestras do conteúdo deste: ${ }^{47}$

Existem cousas justas e permitidas pelo direito das gentes necessário, que as nações podem convencionar mutuamente ou que podem consagrar e fortificar pelos usos e costumes. Existem cousas indiferentes sobre as quais os povos podem entender-se, como quiserem, por meio de tratados, ou pela introdução de costumes ou usos que considerem adequados. Mas todos os tratados e costumes contrários ao prescrito pelo direito das gentes necessário são ilegítimos. ${ }^{48}$

abandonnée jusqu'à ce jour, mais les exemples d'arbitrages offerts et acceptés sont devenus rares de plus en plus, par l'expérience des inconvénients qui semblent être presque inséparables de ce moyen, ordinairement insuffisant, surtout par le défaut d'un pouvoir exécutif'.

43 Cornelis G. Roelofsen (2012, chap. 6, p. 145-169).

44 Cornelis G. Roelofsen (2012, chap. 6, p. 159-162).

45 A respeito, para desenvolvimentos específicos, que não seria pertinente retomar aqui, ver Casella (2012a, esp. cap. VI, 'na formação e no desenvolvimento de Roma', p. 303-334).

46 Vattel (2004, 'Preliminares', § 9): "Desde que esse direito é imutável e as obrigações que ele impõe são necessárias e indispensáveis, as nações não podem alterá-lo por acordo, nem dele se eximir por elas próprias ou por via de reciprocidade".

47 Vattel (2004, 'Preliminares', § 9): “Eis aqui o princípio pelo qual pode-se distinguir os tratados ou convenções legítimos daqueles que não o são, e os costumes inocentes e razoáveis daqueles que são injustos ou passíveis de condenação".

48 Vattel (2004, 'Preliminares', § 9) e prosseguia, na mesma passagem: "Veremos, no entanto, que eles nem sempre estão de acordo com o direito interno, ou de consciência, e mesmo assim por razões dadas em seu próprio lugar, tais convenções e tratados não deixam de ser frequentemente válidos de acordo com o direito externo". O que parece pouco claro. Sobretudo em relação ao passo seguinte, ainda na mesma passagem: "Sendo as nações livres e independentes são elas obrigadas a se conformar com as ações de uma delas, embora ilegítimas e condenáveis segundo as leis da consciência, desde que essas ações não infrinjam direitos perfeitos das mesmas. A liberdade dessa nação não permaneceria completa se as demais nações se arrogassem o direito de inspecionar-lhe a conduta: o que seria contrário à lei natural, que declara toda nação livre e independente das demais". 
Seria esse "direito das gentes necessário", assim, equiparável ao direito natural? ${ }^{49}$ Isso não fica claro em Vattel:

Usamos o termo direito das gentes necessário para aquele direito das gentes que consiste na aplicação do direito natural às nações. Ele é necessário porque as nações são absolutamente obrigadas a respeitá-lo. Esse direito contém os preceitos que a lei natural confere aos estados, os quais não estão menos obrigados a ela que os particulares, porque os estados são compostos de homens e as deliberações são tomadas por homens e porque a lei da natureza obriga todos os homens a terem capacidade para agir. ${ }^{50}$

Em contraposição ao primeiro, ou "direito das gentes necessário", cabe situar o segundo, o "direito das gentes voluntário", que, por natureza, seria decorrente de pactos entre os estados. Vattel assim o explica: “o direito das gentes é a ciência do direito que tem lugar entre nações ou estados, assim como das obrigações correspondentes a esse direito". 51

Desse modo se pode perceber, que Vattel admite, igualmente, a existência de direito 'natural' e direito 'voluntário', na linha de seu mestre, o internacionalista alemão Christian Wolff. ${ }^{52}$ Mas, a obra de Vattel acarreta mudança considerável no modo de tratar o direito internacional, se a consideramos relação ao precedente trabalho de Wolff. Sobretudo na relação entre esses direitos supostamente "necessários" e "voluntários".

Quando Vattel declara "que a sociedade universal do gênero humano é uma instituição da própria natureza, isto é, uma consequência necessária da natureza do homem" 53 - guardadas algumas flutuações terminológicas e modismos deste ou daquele período -, estamos diante do que hoje se chamaria jus cogens, as normas cogentes de

49 Vattel (2004, 'Preliminares', § 8, 'Ele é imutável'): "Sendo assim, o direito das gentes necessário consiste em aplicar o direito natural aos estados, e desde que o direito natural é imutável por estar baseado na natureza das coisas e particularmente na natureza do homem, conclui-se que o direito das gentes necessário é imutável".

50 Vattel (2004, 'Preliminares', § 7) contendo a 'definição do direito das gentes necessário'): Ensaia, ainda na mesma passagem a seguinte explicação: "É esse o mesmo direito que GRÓCIO e seus seguidores chamam de direito das gentes interno, à medida que obriga as nações em consciência. Muitos escritores o designam também de direito das gentes natural".

51 Vattel (2004, 'Preliminares', § 3): “O objetivo desta obra é estabelecer solidamente as obrigações e os direitos das nações". [...] "Será visto neste tratado de que maneira os estados, como tais, devem regular as suas atividades. Avaliaremos as obrigações de um povo para consigo e para com os demais, e, desse modo, consideraremos os direitos resultantes dessas obrigações".

52 Emer de Vattel retoma Wolff em seu último trabalho, publicado em 1762, o ensaio Questions de droit naturel et observations sur le traité du droit de la nature par Mr. le baron de Wolff. A respeito da reputação e legado de Wolff para o direito internacional, ver o Direito internacional no tempo clássico (CASELLA, 2015, cap. XXII, esp. o item 22.2, 'reputação e legado de WOLFF', p. 705-719).

53 Vattel (2004, 'Preliminares', § 11). 
direito internacional geral, que, como tais, obrigam não somente a todos os estados, mas igualmente a todos os homens. Do que não discrepa Vattel: "todos os homens, em qualquer condição, são obrigados a dedicar-se a essa sociedade e a cumprir-lhe os deveres". ${ }^{54}$

A natureza cogente dessas normas de direito internacional é claramente afirmada por Vattel, ao cuidar do que chamou de "direito das gentes necessário" ${ }^{55}$ E isso se manifesta pelo caráter inderrogável de tais normas: "Nenhuma convenção ou acordo particular podem dispensá-los desses deveres". ${ }^{56} \mathrm{E}$, em relação a tais deveres, nem mesmo normas constitucionais de caráter interno poderiam ser contrapostas como excludentes da obrigação de observância e aplicação de referidas normas gerais de caráter internacional:

Quando, pois, os homens se unem em sociedade civil para formar determinado Estado ou Nação, eles podem assumir compromissos particulares com aqueles a que se associem; mas as suas obrigações para com o resto do gênero humano permanecem imutáveis. ${ }^{57}$

Vattel também entendia e exprimia o conteúdo jurídico do que em nossos tempos se denomina a "proteção internacional dos direitos fundamentais", como extensão das obrigações inerentes à natureza e à sociedade humanas:

Toda a diferença consiste em que tendo acordado agirem em comum, e tendo transferido os seus direitos e submetido a sua vontade ao corpo da sociedade em tudo o que interesse ao bem comum, compete doravante a esse corpo, o Estado e a seus dirigentes cumprirem os deveres de humanidade para com os estrangeiros, em tudo quanto não mais depende da liberdade dos particulares, e cabe ao Estado em especial cumprir esses deveres para com outros Estados. ${ }^{58}$

Vattel também exprime a sua concepção da 'sociedade internacional', como 'pessoa jurídica', com entendimento, vontade e poder que lhe são próprios - em

$54 \quad$ Vattel (2004, 'Preliminares', § 11).

55 Vattel (2004, livro I, cap. XXIII, § 283, p. 180-181) como se pode constatar pela redação do trecho já referido na epígrafe, no sentido de ser "da maior importância para as nações que o direito das gentes, base de sua própria tranqüilidade, seja respeitado universalmente". E isso se exprime como dever coletivo, de zelar pela observância e pela aplicação de tais normas, e concretamente, opinava VATTEL, "se alguma nação espezinhar abertamente esse direito, todas podem e devem insurgir-se contra ela, e ao reunirem suas forças, para punir esse inimigo comum". O que se faria em defesa não somente do interesse de cada um, mas igualmente do interesse coletivo, onde as nações assim estariam "cumprindo seus deveres para consigo mesmas, e para com a sociedade humana, da qual são membros". Mesmo se obviamente não utiliza a terminologia 'normas cogentes', VATTEL exprime o conteúdo destas, em sua reflexão, formulada em meados do século XVIII.

56 Vattel (2004, 'Preliminares', § 11).

57 Vattel (2004, 'Preliminares', § 11).

58 Vattel (2004, 'Preliminares', § 11 e antes $\S 5$ ) expunha que "os homens, quando unidos em sociedade, permanecem submetidos às obrigações que a natureza humana lhes impõe". 
contraposição à visão da civitas maxima, antes exposta por seu mestre Wolff. ${ }^{59}$ A concepção de Vattel não destoa da nossa visão corrente, a respeito da 'sociedade internacional', nestes tempos pós-modernos:

Esta sociedade pode ser vista como uma pessoa jurídica, porque ela tem um entendimento, uma vontade e um poder que lhe são próprios. Ela é pois obrigada a viver com outras sociedades ou estados, como um homem era obrigado antes do estabelecimento do estado, a viver com os demais homens, isto é em conformidade com as leis da sociedade natural estabelecida para o gênero humano. ${ }^{60}$

Pode ser questionada a atribuição a Vattel da responsabilidade pela decadência da aceitação da noção de direito natural. ${ }^{61} \mathrm{O}$ que pode ser extensamente debatido. Mas, o que diz o próprio Vattel a respeito? Este utiliza, de maneira recorrente, a expressão 'direito natural', como parte do seu vocabulário e base constante, para a sua argumentação. ${ }^{62}$

Apesar dos elementos recorrentes de 'direito natural', Vattel agrega a essa 'base' de 'direito natural' outros elementos, relacionados com a prática dos estados. Daí ser Vattel considerado paradigma do assim chamado direito internacional do tempo clássico e do iluminismo, como expressão de modelo essencialmente interestatal de direitos e de relações internacionais. Mas, sintomaticamente, Vattel não deixa de recorrer a elementos estranhos à prática dos estados, para fundamentar o seu direito internacional: em suma, por mais relevante que seja a prática efetiva dos estados, o direito internacional não se sustenta, se for entendido e aplicado somente como espelho da prática dos estados.

Por esse motivo, Vattel é considerado expressão paradigmática do direito internacional 'clássico', ${ }^{63}$ com alguma diferença em relação ao que denomino 'direito internacional no tempo do iluminismo'. Jouannet o diz com todas as letras: “ora é assim que, em 1758, emerge realmente o direito das gentes clássico", este no sentido de um conjunto de regras, individualizadas e autonomizadas, destinado a reger uma sociedade

59 A respeito de Wolff e de sua formulação da civitas maxima, como ideal de ordenação da sociedade internacional, ver Casella (2015, cap. XXII, p. 621-719).

${ }_{60}$ Vattel (2004, 'Preliminares', § 11 e 12) enfatizava no parágrafo seguinte: "O fim da sociedade natural, estabelecida entre todos os homens é o de que se prestem assistência mútua para alcançar a própria perfeição e a do seu estado; e as nações tanto quanto pessoas livres vivendo em um estado natural, são obrigadas a cultivar entre si essa sociedade humana".

${ }^{61}$ Horatia Muir-Watt (1987, v. 32, p. 71-83), ressalta não ser adequado imputar a Vattel o declínio da aceitação do direito natural como fundamento do direito das gentes, mas este somente teria trazido precisões ulteriores a doutrina já em gestação junto a seus predecessores da escola do direito da natureza e das gentes.

${ }_{62}$ Vattel (2004, II.IX., 'Dos direitos que subsistem para todas as nações após a introdução do domínio e da propriedade', esp. § 116, 'Quais são os direitos de que os homens não podem ser privados', p. 254): “A natureza não impõe obrigações aos homens sem lhes dar meios para satisfazê-las".

63 Emmanuelle Jouannet (1998). 
internacional não hierarquizada, cujo fundamento é a noção de soberania estatal e cuja finalidade é a de assegurar o respeito a um certo número de direitos e deveres perfeitos dos estados. ${ }^{64}$

Esta visão, segundo entendo, exige algumas qualificações: Jouannet afirma que o direito internacional somente se configura, como sistema, em meados do século XVIII, justamente com a obra de Vattel e as de seus contemporâneos. E que isso não teria ocorrido, como entendem muitos, na primeira metade do século XVII, com Suarez, Gentili e Grócio. ${ }^{65}$ Nesse sentido, Jouannet exprime opinião que eu respeito e aprecio como interpretação, embora não a compartilhe inteiramente:

Afirmando que a teorização do direito internacional clássico somente acontece com Vattel, situamo-nos exclusivamente em plano teórico. Não se busca uma sistematização do direito positivo, tal como possa ter sido realizada por Vattel, mas onde se trata de fazer o estudo do pensamento jurídico vatteliano e de sua gênese teórica. ${ }^{66}$

Esse direito internacional 'clássico', segundo a interpretação de Emmanuelle Jouannet, não se teria consolidado, assim, no início do século XVII, com autores como Gentili, Suarez e Grócio, mas somente em meados do século XVIII, especificamente com Vattel e seus contemporâneos. O aparente impasse pode ser situado, na linha aqui proposta para a compreensão do fenômeno jurídico internacional, em suas fases de evolução, do direito internacional 'moderno' ao ‘clássico', e deste direito internacional 'clássico’ ao direito internacional no 'tempo do iluminismo'.

Ao se colocar o foco na contribuição específica de Vattel, isso não ocorre para fazer abstração do extraordinário trabalho conceitual operado antes dele, pelo conjunto da escola do direito natural e das gentes, e a originalidade do autor de Neuchâtel reside menos, nesse sentido, no tocante ao fundo, propriamente dito, do que na maneira pela qual ele integra, concilia e desenvolve os temas inaugurados por seus predecessores, particularmente pelo célebre filósofo de Halle, Christian Wolff. Considera Jouannet ser, assim, preciso re-situar Vattel, no seio da corrente jusnaturalista, a fim de coletar, dentre as obras de seus predecessores, os traços das teses que ele defendeu, ou daquelas às quais

$\overline{64}$ E. Jouannet (1998, 'Conclusion', § 195, p. 419): "Si 1'on consulte par exemple des ouvrages postérieurs à 1758 , on réalise que le passage de l'ancienne conception à la nouvelle est en effet pleinement acquis à partir de là et le plus souvent à la manière de VATTEL".

${ }_{65}$ Como exposto em Casella (2014). Esse encadeamento de autores e de temas como eixo central, constitutivo do direito internacional moderno é majoritariamente aceito pela doutrina.

${ }_{66}$ Jouannet (1998, 'Introduction', § 2, p. 9 e a seguir, ainda do mesmo parágrafo, cit. p. 16): "VATTEL se détache d'une certaine manière de ses prédécesseurs, non pas en abandonnant la tradition jusnaturaliste, mais en réalisant, au coeur même de cette tradition, la systématisation du droit des gens classique". 
se opôs implicitamente, a fim de lhes buscar a especificidade e fazer valer as implicações ulteriores. ${ }^{67}$

A construção de Vattel constituiu uma das fontes do direito internacional 'clássico', no sentido - aqui situado para esse termo polissêmico ${ }^{68}$ - de ter como foco do sistema as ações dos estados, e ter sido ele impulsionador da adoção de orientação voltada para o positivismo. E se pautaria pela dedução das formulações do direito e das relações internacionais a partir da prática dos estados. Mas, contudo, não se reduz a esses elementos.

A concepção de VATTEL a respeito do direito das gentes acolhe a pluralidade dos estados, e afirma a liberdade soberana de cada um destes para escolher o seu próprio sistema de governo e a confissão religiosa, bem como o princípio da igualdade dos estados, independentemente do tamanho e da força militar de cada um:

\begin{abstract}
Sendo as nações livres e independentes, são elas obrigadas a se conformar com as ações de uma delas, embora ilegítimas e condenáveis segundo as leis da consciência, desde que essas ações não infrinjam direitos perfeitos das mesmas. A liberdade dessa nação não permaneceria completa se as demais nações se arrogassem o direito de inspecionar-lhe a conduta, o que seria contrário à lei natural, que declara toda nação livre e independente das demais. ${ }^{69}$
\end{abstract}

Embora tenha conservado Vattel muitos aspectos do pensamento 'naturalista', herdado de outras eras, ao enfatizar o poder e a autoridade do soberano, na criação e na aplicação de normas, este seria 'positivista'. O que se vê quando Vattel chegar

${ }_{67}$ Jouannet (1998, p. 17) adverte para o risco inerente a tal operação, da qual poderia resultar homogenização de corrente de pensamento muito mais rica e mais variada do que costuma ser reconhecido, onde: "les théories antérieures sont le plus souvent présentées systématiquement comme préparant et annonçant la doctrine de référence dont elle dévoilerait la signification dernière".

68 Cfr. Casella (2015, o item 'o que é, e como é o clássico?', p. 87-175), para definição de alguns aspectos conceituais e exemplos de seus desdobramentos em diferentes áreas do conhecimento e das artes. $\mathrm{O}$ fenômeno 'clássico' se inscreve como modelo cultural, historicamente situado, que se opõe ao precedente modelo 'barroco', afirmando resgatar elementos de era anterior aos assim chamados excessos do barroco, para restabelecer equilíbrio, que pautara o 'renascimento', como este buscara a sua fonte e inspiração na Antiguidade clássica. Por sua vez, após o período 'clássico’ e seu excesso, sob a forma do 'classicismo', se assiste a nova contestação do modelo cultural anterior, com o repúdio à suposta frieza e intelectualização do 'clássico', por parte dos assim chamados 'românticos', que vão, por sua vez, buscar a originalidade e a espontaneidade medievais, e valorizam esse legado também como o tempo de surgimento e de afirmação de distintas identidades nacionais. São estes sintomas ou expressões do movimento pendular da história, que oscila de um modelo a outro, que busca o equilíbrio entre um extremo e outro. A respeito, ver o item ' $d o$ clássico ao direito internacional no tempo do iluminismo' (no início do presente tomo).

69 Vattel (2004, 'Preliminares', § 9, p. 4, e tb. § 22, p. 10): “todos os homens e todos os estados tem um direito perfeito às cousas sem as quais não poderiam sobreviver, porque esse direito corresponde a uma obrigação indeclinável. Logo, todas as nações estão no direito de reprimir pela força aquela que viole abertamente as leis da sociedade que a natureza entre elas estabeleceu, ou que ataque diretamente o bem e a sobrevivência dessa sociedade". 
a levar esse questionamento a ponto de exprimir dúvidas se o direito internacional poderia vincular o soberano.

Vattel inauguraria nova fase do direito internacional. A formulação não deixa de ser contraditória, quando se aponta Vattel como expoente da escola de direito natural (proponent of the school of natural law), mas subordinando o direito internacional positivo ao direito natural (subordinating the positive law of nations to the natural law of nations). ${ }^{70}$

Alguns graves problemas para a evolução futura do direito internacional decorrem desta dicotomia, como abrir as portas do direito internacional ao excessivo voluntarismo dos estados. O que foi levado ao paroxismo no século XIX e parte do século XX. E parece ressurgir em determinados 'negadores' da juridicidade do direito internacional.

Como se pode observar, ${ }^{71}$ existe sintonia entre a obra e o seu tempo: "Vattel teorizou a respeito de direito das gentes ao mesmo tempo 'liberal e pluralista', muito alinhado com o estado da sociedade europeia da época do Iluminismo, e com o pluralismo dessa sociedade anárquica", ${ }^{72}$

Exemplo de tal dicotomia entre 'naturalismo' e 'positivismo', Wolff e também Vattel consideravam razões religiosas como causas injustas para a guerra, ou para uma intervenção no território de outro estado. Mas, apesar de seu apego à liberdade e ao direito de autodeterminação, Vattel admitia a possibilidade de ‘intervenção' para a libertação de outro povo, submetido a governo despótico. O que se aproxima da ideia contemporânea de "intervenção para fins humanitários", mas já encontra eco junto aos revolucionários, e continuaria a ser alegado, muito depois da revolução francesa. ${ }^{73}$

Vattel pode ser tido como parte de fenômeno característico do seu tempo, porquanto internacionalistas do final do século XVIII e do início do XIX, combinavam

70 E. Jouannet (2012, chap. 45, p. 1.119): "he took up one of the most decisive contributions of his mentor WOLFF, and highlights three aspects of the law of nations, the voluntary, the conventional and the customary, in addition to the natural law of nations. [...] He remained a proponent of the school of natural law, subordinating the positive law of nations to the natural law of nations". V. tb. Paul Guggenheim (1956); Yves Sandoz (ed.) (2010).

71 Não por acaso Georges Scelle (1948, p. 44) chamava Vattel de “príncipe dos positivistas". O que pode ser contestado, como aqui se considera.

72 E. Jouannet (2012, p. 1.119-1.120): "It responds to the need to provide a number of small and medium-sized states with the tools to manage their relations at the time when the old feudal or imperial structures were in decline. This was also a time when Europe had begun to emerge from the horrifying wars of religion and needed to find a way of managing relations between states that now had different religions and different subjective concepts of what constitutes a 'good life'. Now VATTEL liberal and pluralist law of nations was perfectly well suited to this situation since its underlying principles are the principle of neutrality or tolerance and vis-à-vis the political regime, the customs and the religion of each state".

73 Heinz Duchhardt (2012, chap. 45, p. 636): "was to remain on the agenda until well after the French Revolution". 
elementos de 'naturalismo' e de 'positivismo', em graus variados, argumentando, por exemplo, que certos princípios universais de direito natural aplicar-se-iam a todas as nações, quer fossem estas 'civilizadas' ou não. Ao mesmo tempo, considerável conjunto de normas, especificamente aplicável às relações intraeuropeias, emergia progressivamente. No paradoxo de 'direito internacional europeu', como exporiam von Martens (1778) e Moser (1778). ${ }^{74}$

Em exame do conjunto da "literatura do direito internacional", von Ompteda (1785, reed. 1963) $)^{75}$ observava a respeito da obra de Vattel (1758), ser esta "valiosa por todos os desenvolvimentos do direito internacional, apresentados de modo bastante adequado, porém não isenta de erros": ${ }^{76}$

Sem dúvida a maior contribuição de Vattel para a ciência do direito internacional foi tomar as duras frases de WOLFF, apresentadas como demonstrações matemáticas, de maneira seca e didática, e as transpor para discurso agradável e mais natural, de tal forma que seu livro, na verdade, ainda em nossos tempos, é praticamente o único dentre os autores a tratar do direito internacional natural (fast das einzige von natürlichen Völkerrecht handelnde Werk ist), que se mantenha em uso junto aos homens de estado, e demais pessoas que não se pautam pela dedicação à erudição.

Isso sem deixar de apontar os erros que a obra contém: primeiro, falta adequada distinção entre o direito internacional e o direito do estado $;^{77}$ segundo, não se pode negar que Vattel faça muitas vezes dos temas tratamento bastante superficial ${ }^{78} \mathrm{e}$, finalmente, dado que ele escreve principalmente para soberanos e homens de estado, devese lamentar muito que ele, na maioria das vezes, em seu discurso, se atenha a considerações genéricas, e não as ilustre mediante exemplos, e as comprove mediante

74 Ver, por exemplo, esse foco em direito internacional especificamente 'europeu', nas obras de Georg F. von Martens (1821) e de Johann. J. Moser (1778), dentre outras.

75 Dietrich Heinrich Ludwig von Ompteda (1963, § 99, p. 338-339): “ein Werk welches eines der berühmtesten im Völkerrecht geworden ist, nehmlich das Vattelsche, unter folgenden Titel" Le droit des gens [...] par M. de Vattel.

76 Von Ompteda (1963, II. Theil, § 139, p. 410-411), mencionava, ademais, a tradução da obra de Vattel para o alemão, feita por Joh. Phil. Schulin (esta publicada em Frankfurt e Leipzig, 1760, em três tomos).

77 Von Ompteda $(1963, \S 99$, p. 346): "Wenn WOLF von letzteren verschiedenes seinem iuris gentium, besonders in 1.sten Capitel, das de officiis gentium erga se ipsas et inde nascentibus iuribus handelt, beymischet, so gehet VATTEL noch viel weiter, und handelt in seinen 1.sten Buche: de la nation considérée en elle-même, welches den dritten Theil seines ganzes Werkes ausmachet, und in denenjenigen Editionen, die in 3. Theile abgetheilet sind, den ganzen ersten Theil einnimmt, fast das ganze allgemeine Staatsrecht $\mathrm{ab}$, indem er, wie er selbst in der Vorrede gestehet, die mehresten Sätze aus WOLFs besonderem Werke vom allgemeinen Staatsrechte herbeyziehet".

78 Von Ompteda (1963, § 99, p. 346): "Hiernächst kann man nicht leugnen, dab VATTEL manchmal zu sehr bey der Oberfläche stehen bleibet, und nicht tief und gründlich genug in die Materien eindringet". 
precedentes da história, sobretudo recente, que poderiam ser úteis para explicar e respaldar a exposição, como faz em sua obra, [Gaspard de] Real, que se destaca em relação a ele. ${ }^{79}$ Tivesse Vattel dado mais atenção a este aspecto, e feito a sua obra com caráter mais prático, esta teria, assim, com certeza, ainda maior utilidade, e seria encontrada com ainda maior freqüência nas mãos dos grandes, e sobretudo nas mãos daqueles que buscam o exercício prático do direito internacional. ${ }^{80}$

A obra de Vattel se tornou uma das mais conhecidas do direito internacional. Sem esquecer a estreita e direta relação desta com a obra do mestre: o próprio autor reconhecia, no prefácio, se tratar de reformulação da obra de Wolff, que ele tinha procurado colocar em forma mais leve e agradável, mas que na verdade, Vattel se mostrava mais completo, ao serem comparadas as obras de ambos.

Mesmo quanto à ordem de exposição das matérias, Vattel tinha seguido muito de perto a sistematização de Wolff. Chegava mesmo Ompteda a apresentar quadro, ${ }^{81}$ no qual cotejava, lado a lado, os índices das obras - para mostrar o paralelismo no desenvolvimento das matérias.

Não somente quanto à ordenação das matérias, Vattel segue cuidadosamente os passos de Wolff, mas, também, em relação ao conteúdo. A 'filiação' intelectual é, ademais, reconhecida pelo próprio Vattel:

É pois necessário, em muitas ocasiões, que as nações padeçam de certos fatos, conquanto injustos e condenáveis em si próprios, porque elas não poderiam a eles opor-se pela força, sem transgredir a liberdade de cada uma delas e sem

$79 \quad$ Von Ompteda (1963,$\S 99$, p. 346): “endlich ist es [...] gar sehr zu bedauern dab er mehrenteils bey dem Vortrage der allgemeinen Sätze des Völkerrechts stehen bleibet, und solche nicht durch Beyspiele und Beweise aus der Geschichte, besonders der neueren, zu erläutern und zu unterstützen suchet, als worunter sich REAL sehr gegen ihn auszeichnet".

80 Von Ompteda (1963, § 99, p. 346): "Hätte VATTEL diesen Vorzug seinem Werke gegeben, und es dadurch practischer gemachet, so würde es gewib noch weit grösseren Nutzen nach sich ziehen, und sich noch weit mehr in den Händen der Grossen und überhaupt dererjenigen befinden, von denen die practische Ausübung des Völkerrechts abhänget".

81 Ompteda (1963, p. 345).

de Wolff (1749) e de Vattel (1758)

capítulo 1 Livro I

capítulo 2 Livro II, caps. 1 a 5

capítulo $3 \quad$ Livro II, caps. 7 a 11

capítulo $4 \quad$ Livro II, caps. 12 a 17

capítulo $5 \quad$ Livro II, cap. 18

capítulo $6 \quad$ Livro III, caps. 1 e 2

capítulo 7 Livro III, caps. 3 a 18

capítulo $8 \quad$ Livro IV, caps. 1 a 4

capítulo 9 Livro IV, caps. 5 a 9 
destruir os fundamentos da sociedade natural de todas. E desde que elas sejam obrigadas a cultivar essa sociedade, presume-se de direito que todas as nações concordaram com o princípio que acabamos de estabelecer. As regras que daí decorrem formam o que WOLFF denomina direito das gentes voluntário, e nada impede que usemos do mesmo termo, ainda que nos afastemos desse homem qualificado, na maneira de estabelecer o fundamento desse direito. ${ }^{82}$

Em Vattel, o caráter egalitário e - em certa medida, anárquico -, da sociedade internacional, se manifesta de modo patente, em decorrência da ausência da ideia de poder colegiado central (civitas maxima), no qual se destaca de Wolff. Dentre aspectos que os diferenciam, se deve assinalar que Vattel além de não aceitar a concepção de Wolff de uma grande república de todos os povos (civitas maxima), também questiona, embora nem sempre de modo totalmente feliz, outras das premissas de Wolff - como por exemplo, quanto ao fato de não ser consentâneo com o direito internacional 'natural', o uso de armas envenenadas na guerra.

Com relação à distinção entre elementos de 'naturalismo' e de 'positivismo', por exemplo, ao direito de comércio, Vattel considera que "a natureza do direito de comprar" não pode ser inscrito entre os direitos perfeitos. ${ }^{83}$ Isso em virtude da liberdade natural dos homens, que podem comerciar ou não, ${ }^{84}$ segundo a extensão na qual escolham exercer essa prerrogativa: "por conseguinte o direito de comprar ou não aquilo de que se tem necessidade não passa de um direito imperfeito". ${ }^{85}$

82 Vattel (2004, 'Preliminares', § 21, 'fundamento do direito das gentes voluntário') enfatizava, na mesma passagem: "Desde que as nações são livres, independentes e iguais, e desde que cada qual tem o direito de decidir em sua própria consciência o que deve fazer para cumprir as suas obrigações, o efeito disto é produzir, pelo menos exteriormente e entre os homens, uma igualdade perfeita de direitos entre as nações, na administração de seus negócios e na busca de suas pretensões. A justiça intrínseca da conduta delas, não compete às demais julgar definitivamente, destarte, o que se permite a uma, a outra também é permitido, e elas devem ser consideradas na sociedade humana como tendo direitos iguais. Cada nação pretende ter a justiça de seu lado nas controvérsias que possam surgir; e não compete a nenhuma das partes interessadas, nem às demais nações, julgar a questão. Aquela que estiver errada peca contra a sua consciência; mas como pode ocorrer que ela tenha direito, não se pode acusá-la de violar as leis da sociedade".

83 Vattel (2004, I.91, 'Natureza do direito de comprar', p. 65-66): "Pela maneira com que temos demonstrado o direito que uma nação tem de comprar de outras o que lhe falta, é fácil ver que esse direito não é daqueles que são chamados perfeitos e que são acompanhados do direito de coerção".

84 Vattel (2004, I.91, 'Natureza do direito de comprar', p. 65-66): "Vós tendes o direito de comprar de terceiros cousas que vos faltem e das quais eles não tem necessidade: vindes a mim, mas eu não sou obrigado a vendê-las se eu próprio delas precisar. Em virtude da liberdade natural que pertence a todos os homens, cabe a mim julgar se delas tenho necessidade ou se estou numa posição de vendê-las; e não cabe a vós decidir se eu julgo bem ou mal, porque não tendes nenhuma autoridade sobre mim".

85 Vattel (2004, I.91): "como aquele que tem um pobre de receber esmola do rico; se este recusa dá-la, o pobre tem razão de queixar-se, mas ele não tem o direito de obtê-la pela força". 
Pelo modo como demonstramos o direito que possui uma nação de adquirir em outras aquilo que lhe faz falta, é fácil ver que esse direito não é daqueles que se chamam perfeitos, e que vão acompanhados do direito de sanção. [...] Se eu me recuso a vender, por seu justo preço, aquilo de que o outro tem necessidade, eu falto contra o meu dever; pode o outro deplorar isso, mas não pode me obrigar a mais do que tanto, sem violar a minha vontade natural e me infligir uma injúria.

De um lado, Vattel admite que, em determinados casos, um estado possa tomar a força as coisas de que tenha necessidade, ${ }^{86}$ e prossegue a sua formulação, de que o direito (imperfeito) de comércio pode se tornar perfeito, se for convencionado por meio de tratado: $: 87$

os homens e os estados soberanos podem se obrigar, por meio de promessa, àquilo que a natureza somente os obriga imperfeitamente. Uma nação que não tem o direito perfeito de exercer o comércio, pode aperfeiçoá-lo por meio de um pacto ou de um tratado. Por conseguinte, o direito de comércio somente se estipula por meio de tratados, e deve ser compreendido no âmbito do direito das gentes, que denominamos convencional. O tratado que confere direito ao comércio constitui a medida e a regra deste.

Barcia Trelles (1927) comparava a extensão da formulação do direito de comércio em Vattel e em Vitória. E, previsivelmente, conclui a favor de seu conterrâneo, em comparação com os limites a tanto estipulados por Vattel, duzentos anos mais tarde. ${ }^{88}$ Outra contradição pode ser apontada ${ }^{89} \mathrm{em}$ Vattel, com relação ao direito de intervenção. Como, ademais, também se produz em von Martens.

86 A questão dos limites do exercício do direito de comércio entre as nações se liga ao que mais adiante considera Vattel, quanto a determinar e em que extensão um estado poderia tomar a força aquilo de que tenha necessidade. Ver Vattel (2004, II.IX., 'Dos direitos que subsistem para todas as nações após a introdução do domínio e da propriedade', p. 254-261): “A natureza não impõe obrigações aos homens sem lhes dar meios para satisfazê-las. Eles tem direito absoluto ao uso necessário de tais meios e nada pode privá-los desse direito, como nada pode dispensá-los de suas obrigações naturais".

87 Vattel (2004, I.VIII.93, 'Como se adquire um direito perfeito em comércio exterior', p. 67).

88 Camilo Barcia Trelles (1927, v. 17, p. 109-342, Seconde partie, chap. II, 'Le droit de commerce', p. 206-218, cf. p. 207 e a seguir p. 213): "Le droit de commerce étant imparfait, on ne saurait exiger qu'il soit accordé et par suite, on ne saurait se livrer à aucun acte de coercition contre le peuple récalcitrant. Voilà comment la sanction est éliminée".

89 Camilo Barcia Trelles (1927, v. 17, p. 109-342, Seconde partie, chap. III, 'Le droit d'intervention et la solidarité internationale', p. 219-231). 
No entendimento de Vattel, "os direitos cuja reunião constitui a soberania podem ser divididos" ${ }^{90}$ Essa divisibilidade da soberania pode ser feita, "se a nação assim desejar". 91

Essa argumentação a respeito da divisibilidade da soberania suscita muitos debates, até hoje. Naquela altura, foram publicadas na França e na Holanda, as "máximas de direito público", Maximes du droit public (1772), sem nome de autor, mas cuja autoria se costuma reconhecer a quatro advogados junto ao parlamento de Paris, o abade Mey, bem como Maultrot, Aubry e Blonde. ${ }^{92}$

Dentre muitas outras matérias, nessa obra, ${ }^{33}$ defendia-se o direito de 'resistência à opressão' - ou seja, o povo pode derrubar os governos que tenham agido de maneira contrária aos fins para os quais tinham sido revestidos de autoridade, como acabara de ocorrer na Suécia, em 1772:94 também se admitia que a nação pudesse escolher o seu rei, como tinha ocorrido na Inglaterra, e que a regra de sucessão automática por herança não passaria de inovação daqueles tempos. Concretamente, as leis fundamentais e a própria forma de governo poderiam ser mudadas pelos estados gerais - hoje diríamos, por uma 'assembleia constituinte'.

$\mathrm{O}$ que aqui nos interessa, citavam-se, também, nas máximas de direito público (1772), a obra de Vattel e a aceitação deste da divisibilidade da soberania. A posição francesa é mais conservadora nessa matéria - e isso parece repercutir até hoje, entre juristas franceses. Para quem reluta em aceitar a divisibilidade da soberania e do

90 Vattel (2004, I.III, $§ 31$, 'Direitos da nação quanto à sua constituição e ao seu governo', p. 28): “O governo não é estabelecido senão para a Nação, tendo em vista a preservação e a felicidade desta". Ver tb. Vattel (2004, I.IV, 'Do soberano, de suas obrigações e de seus direitos', § 45, 'Amplitude de seu poder, direitos de majestade', p. 35): "Se a nação lhe tem conferido pura e simplesmente a soberania, sem limitações e sem partilha, considera-se ter-lhe conferido todos os direitos sem os quais o poder soberano, ou o império, não pode ser exercido da maneira mais conveniente para o bem público".

91 Vattel (2004, III.II, § 7, p. 410-411): "Pode acontecer, pois, que a nação não confie a seu dirigente um direito tão perigoso para a sua liberdade - o de recrutar tropas e mantê-las armadas, ou que ela limite ao mínimo o exercício desse direito - fazendo-o dependente do consentimento da sua assembleia representativa".

92 Patrick Arabeyre, Jean-Louis Halpérin et Jacques Krynen (2008, p. 562) a respeito de Claude Mey (17121796): "MEY a égalément oeuvré avec MAULTROT et AUBRY à la première édition des Maximes du droit public français (1772), imposant manifeste d'opposition à la réforme MAUPEOU et aux principes de l'absolutisme monarchique".

93 Observa Philippe Nemo (2002, 'La suspension des Parlements sous MAUPESCU et les Maximes du droit public', p. 458-460): “Ce gros traité érudit vise essentiellement établir les droits législatifs et fiscaux des cours souveraines. Mais il est précédé d'un traité complet de philosophie politique. Or cette philosophie est à peu près celle de LOCKE. Tous les auteurs de la théorie moderne du droit naturel sont cités, de GROTIUS et PUFENDORF (et leur traducteur en français, BARBEYRAC) à VATTEL et à BURLAMAQUI (et HOBBES est réfuté)".

94 A respeito da retomada do absolutismo na Suécia, durante o reinado de Gustavo III, ver H. Lindqvist (2002, p. 404-478); Neil Kent (2010, cap. 5 - 'The collapse of absolutism and the age of freedom', p. 101-128; cap. 6 - 'Royal absolutism restored', p. 129-148, cap. 7 - 'Constitutional Sweden', p. 149-171). 
exercício de competências soberanas, cabe lembrar a lição de Vattel, para quem a soberania pertence propriamente à nação. A nação pode delegar a soberania, mas não a pode alienar.

A formulação de Vattel a respeito da 'soberania' é bastante inovadora. Sobretudo para seu tempo. ${ }^{95}$ Para Vattel, ${ }^{96}$ a 'soberania', como direito precioso de cada estado, exclui o direito de intervenção. Este expõe o seu pensamento a respeito do tema: é consequência patente da liberdade e da independência das nações, que todas tem o direito de se governarem por si mesmas, como escolherem, e nenhuma (soberania) tem o direito de me imiscuir no governo de outra. De todos os direitos que pode ter uma nação, nenhum é mais apreciado que o da soberania, aquele que as demais nações devem respeitar escrupulosamente, se não querem infligir injúria.

Mas depois de ter tão categoricamente afirmado o princípio da soberania e da não ingerência nos assuntos internos, logo a seguir, o direito de intervenção é apontado como aceitável, ao menos em duas ocasiões, que Vattel considera legítimas:

- quando se trata de apoiar com armas o povo que se revolta contra uma tirania, e busca a sua liberdade, baseando-se no fato de que a guerra civil dá origem a duas autoridades independentes - seria, assim, resguardada a possível legitimidade de intervenção, quando resulte em secessão; e

- quando se trata de defender a legitimidade da luta contra soberano estrangeiro que se conduza como um monstro, desse modo, Vattel contradiz, novamente, o princípio antes formulado - resguardando a legitimidade do que em nossos tempos seria chamada a 'intervenção humanitária' - o que pode suscitar não menos numerosas controvérsias e abusos.

Afirmava Vicente Marotta Rangel (2004): “o tratado de Vattel é uma das principais obras escritas no século XVIII". ${ }^{97}$ Embora se possa questionar qual a importância da inovação de Vattel - pela extensão na qual simplesmente resume ou reformula capítulos inteiros da obra de Wolff, como mencionado ${ }^{98}$ - mesmo assim, foi marcante sua presença e extensa a aplicação de sua obra. Tenha esta ou não caráter próprio e relevante, em relação às ideias de seu mestre. Ressalta, ainda, quanto sob o prisma doutrinário, "Vattel difere

95 Compare-se a concepção da 'soberania', exposta por Jean Bodin quase duzentos anos antes de Vattel. A respeito, ver Casella (2012b, p. 525-602) esp. cap. XIII, 'estado como sujeito de direito internacional - a contribuição de MAQUIAVEL e BODIN'.

96 Vattel (2004, cf. Livro III, cap. IV).

97 No "prefácio" à tradução de Vattel (2004, p. xlvii et seq.), frisa V. Marotta Rangel: "para situar-nos apenas no âmbito do direito internacional, cabe lembrar que assim como o De jure belli ac pacis, de Hugo GRÓCIO, exerceu no século XVII maior influência que os ensinamentos de Francisco de VITÓRIA, o tratado de VATTEL eclipsou, como assinala Paul REUTER, Institutions internationales (Paris: PUF, 1955, p. 47), tão logo publicado, o livro do jurisconsulto holandês".

98 A respeito, ver tb. Casella (2015, cap. XXII, p. 621-719). 
dos antecessores, à medida que introduz separação mais nítida entre direito natural e direito positivo, entre moral e direito, contribuindo, de certo modo, para o fortalecimento do voluntarismo jurídico, que até hoje tem infelizmente persistido".99

Objeto de controvérsia permanece a filiação intelectual de Vattel, na medida em que outros autores entenderam cabível filiar Vattel à chamada linha naturalista do direito internacional, ${ }^{100}$ ou mesmo alguns criticam a solidez de sua formação jurídica. ${ }^{101}$ Para A. Mallarmé (1904), ${ }^{102}$ inseria-se Vattel na mesma "tradição grociana que, no final do século XVII e começo do século XVIII", ao reagir "contra as diferentes teorias de base no direito natural, sobretudo na versão, ensinada por Samuel Pufendorf". ${ }^{103}$ Esta contradição não foi a única.

Pode-se, de um lado, argumentar que Vattel deixa de lado a concepção teórica de Wolff - com a proposta da civitas gentium maxima - e se preocupa com a dimensão prática do direito internacional, tal como entendido e aplicado pelos estados. Essa escolha, contudo, não é destituída de graves consequências: pois, quando Vattel abandona a concepção da civitas maxima de Wolff ${ }^{104}$ e põe seu foco na soberania e nas relações entre os estados, este enfraquece o fundamento objetivo do direito internacional.

99 V. Marotta Rangel (VATTEL, 2004, p. lvi e p. 1xii): “O tratado reflete a realidade das relações políticas internas e internacionais da época em que foi escrito, sem ignorar as contribuições do pretérito em relação aos diversos tópicos nele examinados. Essa realidade induziu VATTEL a tentar aclarar a tormentosa dialética entre soberania e direito internacional".

100 Urban Whitaker (1964, p. 29-30): "VATTEL's strongest leanings toward natural law doctrine are evidenced in his constant references to equality. His most famous sentence declares that 'a dwarf is as much a man as a giant is'. Applied to international law, this rule suggests that small nations have equal rights with large ones. This doctrine, which has prevailed to the present day, is severely attacked by BRIERLY as 'a misleading deduction from unsound premises'. It is still quoted with approval, however, by spokesmen for the small new states of Asia and Africa".

101 A. Truyol y Serra (1995, p. 89-90): “Bien que prétendant à présenter les idées de WOLFF d'une façon claire et facile à comprendre, Le droit des gens de VATTEL est plus qu'une glose. Il aborde des nombreuses questions que WOLFF n'avait pas traitées, ou qu'il n'avait fait qu'effleurer. L'expérience du diplomate et du conseiller, bien que réduite au moment où il fut rédigé, se fait sentir. Il manque pourtant à VATTEL une formation juridique adéquate. Le raisonnement est souvent superficiel, et l'expression, grandiloquente. / 'L'ouvrage de VATTEL, malgré les critiques dont il a été l'objet de la part des internationalistes en raison des faiblesses dont nous avons fait état, connut un succès seul comparable à celui de GROTIUS sur le droit de la guerre et de la paix, notamment dans la jurisprudence des tribunaux en Angleterre et aux États-Unis. Le secret de cette diffusion, jugée paradoxale par certains (dont NUSSBAUM), doit être cherché dans la nature même du traité, dont on a pu dire, à juste titre, par rapport à son modèle, qu'il 'n'était pas l'ouvrage d'un savant pour des savants, dans un latin obscur, lourdement scholastique, mais un livre élégamment écrit par un homme du monde, un diplomate, philosophe et lettré, à l'intention des souverains, des ministres et des gens du bel air' (Albert de LA PRADELLE). Il fut, jusqu'en plein xix ${ }^{\mathrm{e}}$ siècle, le livre de chevet des diplomates, notamment des consuls, et, dans les pays de langue anglaise, des juges".

102 André Mallarmé (1904, p. 481-601). A respeito de Pufendorf, ver o Direito internacional no tempo clássico (CASELLA, 2015, cap. XX, p. 405-571).

103 André Mallarmé (1904, p. 481).

104 A respeito de Wolff e a concepção da civitas maxima, como ideal de ordenação da sociedade internacional, ver Casella (2015, cap. XXII, p. 621-719). 
Porque, na medida em que os estados se fazem os únicos juízes de seus atos, de seus direitos e deveres, se relativiza a fundação do sistema. E a mesma questão permanece central, ainda no direito internacional pós-moderno.

Se de um lado caminha-se rumo à concepção mais consentânea com o espírito dos tempos que viriam, e que se coaduna com visão positivista do fenômeno jurídico internacional, por outro lado, a adoção da igualdade soberana dos estados, e a colocação desta como o critério ordenador, para o conjunto das relações entre estados, enquanto sujeitos de direito internacional, ${ }^{105}$ tem esta igualdade, entre outras consequências, a de tornar legítima a 'guerra entre iguais', uma vez que os procedimentos formais sejam observados. Passo irreversível é dado, quando essa legitimação torna-se puramente formal, ou seja, considerar-se-á independentemente das causas, pelas quais possa ser desencadeado um conflito. ${ }^{106}$

O perigo reside nessa relativização. ${ }^{107} \mathrm{E}$ as consequências se fazem sentir, no tempo de Vattel e permanecerão no futuro - até que se comece o esforço para a proscrição da guerra como meio 'legítimo' de exercício da política internacional, pelos estados. O que foi ensaiado, após a primeira guerra mundial, pelo Pacto de Paris, e mesmo depois da segunda guerra mundial e da Carta da ONU, até hoje não se viu plenamente efetivado.

Na obra de Vattel ocorre, também, a preocupação em relação ao "homem honesto e o cidadão", no sentido de dar-lhe "armas para defender o bom direito e para compelir aos menos os injustos a respeitarem alguma medida e a manterem-se nos limites da decência". ${ }^{108}$ Como se faz isso? A questão permanece atual e relevante.

Esta seria a recompensa para qualquer autor, que tente fazer respeitar o direito, e almeje compelir os injustos a respeitarem os princípios - em qualquer tempo e lugar, inclusive no tempo presente. O que não foi e não é fácil.

Pode-se considerar que o direito internacional de Vattel, formulado no seu Droit des gens (1758), era o "direito internacional baseado nos princípios de 1789", enquanto Grócio teria escrito o direito internacional do absolutismo, Vattel escreveu o direito internacional da liberdade política - formulava Albert de La Pradelle

105 Comparem-se exames da matéria feitos com mais de cinquenta anos de distância por dois internacionalistas de orientação bastante distinta como James B. Scott (1932, v. 42, p. 467-630) e Ram P. Anand (1986, v. 197, p. 9-228).

106 Vattel (2004, livro iii, “da guerra”, p. 407-589).

107 Além dos referidos estudos de J. B. Scott (1932) e R. P. Anand (1986), v. tb. Pieter Hendrik Kooijmans (1964).

108 Vattel (2004, livro iv, cap. ix, par. 127, “conclusão”, p. 685): "Será muito para mim se meus princípios forem considerados sólidos, luminosos e suficientes às pessoas esclarecidas, para encontrarem soluções em questões de pormenor em casos específicos. Estarei feliz se o meu trabalho for de utilidade às pessoas que têm amor ao gênero humano e que respeitam a justiça; se o meu trabalho lhes fornecer armas para defender o bom direito e para, ao menos, compelir os injustos a serem respeitosos em alguma medida e a se manterem nos limites da decência!". 
$(1916)^{109}$ - e isso, tanto mais, porque Vattel efetivamente assinala o papel do princípio da não intervenção, ao argumentar a necessidade lógica deste, para sistema de direito internacional, baseado na igualdade jurídica entre os estados.

A formulação de A. de La Pradelle (1916), a respeito de Vattel como arauto do "direito internacional da liberdade política" pode ser bela, mas não me parece consistente. Com toda a consideração devida, La Pradelle parece esquecer que Vattel, em outra passagem, defende o direito de intervenção.

Como reportado, Vattel ${ }^{110}$ quando considera a 'soberania' como direito precioso de cada estado, exclui o direito de intervenção. Mas depois de ter tão categoricamente afirmado o princípio da soberania e da não-ingerência nos assuntos internos, logo a seguir Vattel considerava legítimo o direito de intervenção, apontado como aceitável, ao menos em duas ocasiões. ${ }^{11}$ A contradição é flagrante, e não pode ser menosprezada.

Ainda a respeito da suposta concepção libertária do direito internacional em Vattel, ponderava Onuma Yasuaki (1993), ${ }^{112}$ "essa avaliação de Vattel não é imparcial”. Onuma descreve tal avaliação como parcial (one-sided).

Muda, consideravelmente, a percepção libertária desta concepção doutrinária, quando vista no contexto da colonização europeia das Américas. Pelo fato de ter servido para justificar a conquista e a ocupação colonial da América, a teoria de Vattel tem outros aspectos, menos positivos:

\begin{abstract}
a teoria de Vattel foi fortemente influenciada por Locke, que santificava a propriedade como conceito absoluto, por meio da ideia de que a titularidade da propriedade é produto do investimento do trabalho humano sobre a terra. Esse foi dado teórico importante, para superar a visão de HOBBES, segundo quem, em razão da escassez de recursos e o princípio comportamental do desejo de autopreservação do homem, concluíra que a condição humana era uma guerra de todos contra todos (bellum omnium contra omnes). Contudo, quando a teoria de LOCKE foi 'aplicada' [coercitivamente]
\end{abstract}

\footnotetext{
109 A. de La Pradelle, Introduction (1993, p. III a LV). Ver tb. a respeito, do mesmo Albert de La Pradelle (1950).

110 Vattel (2004, cf. Livro III, cap. IV).

111 Vattel (2004, cf. Livro III, cap. IV), como mencionado, seriam duas as hipóteses 'legitimadoras' de intervenção: (a) quando se trata de apoiar com armas o povo que se revolta contra uma tirania, e busca a sua liberdade, baseando-se no fato de que a guerra civil dá origem a duas autoridades independentes - seria, assim, resguardada a possível legitimidade de intervenção, quando resulte em secessão; e (b) quando se trata de defender a legitimidade da luta contra soberano estrangeiro que se conduza como um monstro, desse modo, Vattel contradiz, novamente, o princípio antes formulado - resguardando a legitimidade do que em nossos tempos seria chamada a 'intervenção humanitária' - o que pode suscitar não menos numerosas controvérsias e abusos.

112 Onuma Yasuaki (1993b, Appendix, p. 371-386).
} 
às relações entre os colonizadores ou conquistadores que chegaram ao 'Novo mundo', provenientes da Europa, e os habitantes autóctones da América e Oceania, isso serviu para justificar que os primeiros tomassem as terras dos últimos. A teoria de Locke permitiu aos colonizadores europeus considerar as terras nas quais viviam os habitantes originais, segundo o seu próprio conceito de trabalho, em condição de população escarsa, como sendo terra de ninguém, à qual o trabalho não tinha sido adicionado, e sobre a qual a titularidade não tinha assim, sido estabelecida. ${ }^{113}$

John Locke (1632-1704), em seus “dois tratados sobre o governo" (1690, ed. 2005), ${ }^{114}$ especialmente no segundo tratado sobre o governo civil - frequentemente refere a situação na América, ao expor a sua teoria sobre a origem da propriedade: ${ }^{15}$

A natureza fixou bem a medida da propriedade pela extensão do trabalho e da conveniência de vida dos homens. O trabalho de nenhum homem seria capaz de dominar ou de apropriar-se de tudo nem poderia o seu desfrute consumir mais do que uma pequena parte. De modo que era impossível a qualquer homem usurpar dessa forma os direitos de outro ou adquirir uma propriedade em prejuízo do vizinho, que ainda teria espaço para uma posse tão boa e tão grande (depois que o outro houvesse tomado a sua) quanto a que havia antes da apropriação. Tal medida confinava a posse de cada homem a uma proporção bastante moderada, tanta quanto ele pudesse apropriar para si sem causar injúria a quem quer que fosse, nas primeiras eras do mundo, quando os homens estavam mais em perigo de se perderem por se afastarem da companhia dos demais, nos vastos ermos da terra de então, do que de serem pressionados pela falta de espaço no qual plantar". ${ }^{116}$

Desse modo, as diferenças de estilos de vida, em contextos culturais diversos, foram apresentadas como preguiça, ou falta de dedicação ao trabalho:

E a mesma medida pode ainda ser admitida, sem os prejuízos de quem quer que seja, por mais repleto que o mundo pareça estar. Pois suponhamos um homem, ou uma

\footnotetext{
113 Onuma (1993b, Appendix, p. 371-386). Sobre a questão do 'eurocentrismo' no direito internacional, ver tb. Arnulf Becker Lorca (2016) e, do mesmo Becker Lorca (2012, cap. 43, p. 1.034-1.057).

114 John Locke (1960); tb. na edição brasileira, Dois tratados sobre o governo civil (LOCKE, 2005); ver, no segundo tratado, esp. II.36, 41, 43, 46, 48, 49 .

115 J. Locke (2005, II.31, p. 412), An essay concerning the true original, extent and end of civil government: "Tanto quanto qualquer pessoa possa fazer uso de qualquer vantagem da vida antes que se estrague, disso pode, por seu trabalho, fixar a propriedade. O que quer que esteja além disso excede a sua parte e pertence aos outros".

116 Locke (2005, II.36, 415-417).
} 
família, no estado em que se encontravam quando o mundo começou a ser povoado pelos filhos de Adão ou de Noé, caso ele plantasse em alguma das terras incultas do interior da América, veríamos que as posses que poderia amealhar para si mesmo segundo as medidas que apresentamos não seriam muito grandes e tampouco, mesmo nesses dias, não prejudicariam o resto dos homens ou lhes dariam motivo para se queixarem ou se julgarem lesados pela usurpação desse homem, embora a raça dos homens se tenha hoje espalhado por todos os cantos do mundo e exceda infinitamente o pequeno número que havia no princípio. Além disso, sem trabalho a extensão de terra é de tão pouco valor que ouvi afirmar que na própria Espanha permite-se que um homem are, semeie e colha sem ser perturbado em terras sobre as quais ele não tem outro direito além de fazer uso delas. Ao contrário, os habitantes sentem-se obrigados para com aqueles que, com seu esforço em terras abandonadas e consequentemente incultas, tenha aumentado o volume de grãos de que eles tinham necessidade. ${ }^{117}$

O inteiro processo de colonização forçada da América pelos europeus pôde assim ser justificado com base na doutrina do investimento do trabalho humano sobre a terra: "não pode haver demonstração mais clara disso do que a feita pelas diversas nações americanas, que são ricas em terras e pobres em todos os confortos da vida; às quais a natureza abasteceu tão generosamente quanto a qualquer povo com os materiais da fartura", e considerava Locke, "um solo fecundo, apto a produzir em abundância o que poderia servir de alimento, agasalho e deleite. E, contudo, por não ser melhorado pelo trabalho, não tem um centésimo das conveniências de que desfrutamos". ${ }^{118}$

Enfatizava Locke (1690, ed. 2005): "é o trabalho que confere a maior parte do valor à terra, sem o qual ela mal valeria alguma coisa. É a ele que devemos a maior parte de seus produtos úteis". ${ }^{119}$ E prosseguia com o exemplo da colonização europeia da América:

A maior parte das coisas realmente úteis à vida do homem, como as que a necessidade de sobreviver fez os primeiros membros das comunidades do mundo buscarem, como hoje fazem os americanos, são em geral coisas de curta

117 Locke (2005, II.36, 415-417): “ouso afirmar que a mesma regra de propriedade, segundo a qual cada homem deve ter tanto quanto possa usar estaria ainda em vigor no mundo, sem prejuízo para ninguém, conquanto há terra bastante no mundo para o dobro dos habitantes, se a invenção do dinheiro e o acordo tácito dos homens no sentido de lhe acordar um valor não houvesse introduzido (por consenso) posses maiores e um direito a estas".

118 Locke (2005, II.41, 421) arrematava essa passagem: "E o rei de um território largo e fértil de lá alimenta-se, veste-se e mora pior do que um trabalhador diarista na Inglaterra".

119 Locke (2005, II.43, 423). 
duração que, se não forem consumidas pelo uso, apodrecem e perecem por si mesmas. [...] Ora, dessas coisas boas que a natureza forneceu em comum qualquer homem tinha o direito (como já foi dito) a quanto pudesse usar, e tinha a propriedade sobre tudo quanto pudesse afetar com seu trabalho; a ele pertencia tudo quanto o seu esforço pudesse abarcar, para alterar do estado em que a natureza o deixara. ${ }^{120}$

Punha assim Locke uma relação direta entre "os diferentes graus de esforço lograram conferir aos homens posses em proporções diferentes" e "a invenção do dinheiro deu-lhes a oportunidade de continuá-las e aumentá-las". ${ }^{121}$ Enfatizava a imagem da América como 'paraíso terreno' ou campo de experimentação de seu modelo de sociedade:

Portanto, no princípio, o mundo inteiro era a América; ainda mais que hoje, pois nada semelhante ao dinheiro era conhecido em parte alguma. Descubra-se qualquer coisa que tenha o uso e o valor do dinheiro entre os vizinhos e ver-se-á que o mesmo homem começará logo a ampliar suas posses. $^{122}$

Como dado característico do que aqui se denomina o direito internacional no tempo do iluminismo, observa Onuma (1993): “deve ser notado que essa era de colonização em larga escala do continente americano pelos europeus foi considerada como a era do Iluminismo - the era of the Enlightenment". Sintomaticamente, o uso do termo 'civilização' também surge nesse período. ${ }^{123}$

A ideia de progresso toma corpo, primeiro com Turgot $(1750)^{124}$ e depois, mais paradigmaticamente, com Condorcet (1795). ${ }^{125}$ A crença no poder conquistador do Iluminismo, baseado na ciência moderna, domina toda essa era. ${ }^{126}$

120 Locke (2005, II.46, 425-426).

121 Locke $(2005$, II. 48,427$)$.

122 Locke (2005, II.49, 427-428).

123 Cf. se examina em Casella (2020, no prelo).

124 Dentre as obras do estadista e economista francês, Anne Robert Jacques TURGOT (1727-781), cabe destacar seu Discours sur les progrès successifs de l'esprit humain («prononcé le 11 décembre 1750») no qual ainda utilizava a seguinte formulação: "Les nations, séparées par de vastes espaces, et plus encore par la diversité des langages, inconnues les unes aux autres, furent presque toutes plongées dans la même barbarie où nous voyons encore les Américains indigènes". (TURGOT, 2016).

125 Nicolas de Condorcet (1759), redige seu ensaio nos seus últimos meses de vida, quando foi obrigado a se esconder em casa de Madame Vernet, em Paris, depois de publicada decretação de ordem de prisão contra ele. Ver tb. Catherine Kintzler (1987).

126 Onuma (1993b, p. 381). O Oxford English Dictionary menciona o primeiro uso do termo 'civilization' em 1704; e situa em 1772 a primeira menção, para designar 'civilized condition or state'. V. tb.: Niall Ferguson (2010), do original Empire (C 2003; Jacques Frémeaux (2010); Jacques Marseille (2005); Henri Wesseling 2009), do original holandês Europa's koloniale eeuw: de koloniale rijken in de negentiende eeuw, 18151919 (c) 2003. 
Daí advém a nefasta consequência da concepção de Vattel sobre a 'colonização' da América, na medida em que a teoria de Vattel foi amplamente aceita nos Estados Unidos. Isso se dá, em parte, por ter sido ele crítico do absolutismo, e mesmo reconhecido o direito de secessão, em relação a regimes despóticos. Ao mesmo tempo, deve-se lembrar que a sua teoria da aquisição colonial convenientemente justificou a expulsão dos habitantes originais ameríndios pelos colonizadores europeus. ${ }^{127}$

$\mathrm{O}$ direito internacional moderno formou-se e desenvolveu-se como sistema jurídico fechado, primariamente para regular as relações entre corpos políticos independentes na Europa. Envolvia povos não europeus, por meio do processo no qual estes eram ou colonizados pelas potências europeias, ou, caso a sua condição independente fosse reconhecida, trazidos para esferas de influência europeia. Povos vivendo em áreas não europeias eram basicamente não mais do que objetos, alienados do direito internacional.

Dessa forma, o direito internacional 'moderno' serviu como ideologia para justificar a relação entre as potências europeias dominantes e povos não europeus subordinados. O mais significativo é o fato de tal justificação ter sido feita por meio da combinação de noções modernas, tais como igualdade e universalidade, liberadas de qualquer contexto ou crença religiosa específica, e a superioridade do poder físico, por parte dos europeus. E já se podia ver essa combinação na relação entre a Espanha e os ameríndios, desde o início da conquista colonial.

São Paulo, 30 junho de 2020.

\section{Referências}

ALEXANDROWICZ, Charles Henry. Treaty and diplomatic relations between European and South Asian powers in the seventeenth and eighteenth centuries. Recueil des Cours of the Academy of International Law, Leiden, v. 100, p. 203-322, 1960.

ANAND, Ram Prakash. Sovereign equality of States in international law. Recueil des Cours of the Academy of International Law, Leiden, v. 197, p. 9-228, 1986.

ARABEYRE, Patrick; HALPÉRIN, Jean-Louis; KRYNEN, Jacques (dir.). Dictionnaire historique des juristes français: $\mathrm{XII}^{\mathrm{e}}-\mathrm{XX}^{\mathrm{e}}$ siècle. Paris: PUF, 2008.

BARCÍA TRELLES, Camilo. Francisco de Vitória et l'école moderne du droit international. Recueil des Cours of the Academy of International Law, Leiden, v. 17, p. 109-342, 1927.

\footnotetext{
127 Y. Onuma (1993b, p. 381): "Rules regulating state responsibility, the validity of unequal treaties, and VATTEL's theory relating to colonization are only examples of the hierarchical structure and justificatory function of modern international law".
} 
BECKER LORCA, Arnulf. Eurocentrism in the history of international law. In: FASSBENDER, Bardo; PETERS, Anne. The Oxford handbook of the history of international law. Oxford: Oxford University Press, Nov. 2012. p. 1.034-1.057.

BECKER LORCA, Arnulf. Mestizo international law: a global intellectual history 1842-1933. Cambridge: Cambridge University Press, 2016.

BURKE, Edmund. Speeches on the impeachment of Warren Hastings. In: KRAMINCK, Isaac (ed.). The portable Edmund Burke. London: Penguin Group, 1999. p. 388-406.

CASELLA, Paulo Borba. Direito internacional nas arcadas: a aula inaugural de 16 de fevereiro de 2009. Revista da Faculdade de Direito da Universidade de São Paulo, São Paulo, v. 104, p. 931966, jan./dez. 2009.

CASELLA, Paulo Borba. Direito internacional no tempo antigo. São Paulo: Atlas, 2012a.

CASELLA, Paulo Borba. Direito internacional no tempo clássico. São Paulo: Atlas, 2015.

CASELLA, Paulo Borba. Direito internacional no tempo medieval e moderno até Vitoria. São Paulo: Atlas, 2012b.

CASELLA, Paulo Borba. Direito internacional no tempo moderno de Suarez a Grócio. São Paulo: Atlas, 2014.

CASELLA, Paulo Borba. Droit international, histoire et culture. Recueil des cours de l'Académie de droit international de La Haye, Leiden, 2020. No prelo.

CONDORCET, Jean-Antoine-Nicolas de Caritat, Baron de. Esquisse d'un tableau historique, desprogrès de l'esprit humain: ouvrage posthume de Condorcet. Paris: Chez H. Agasse, 1795.

DAFFLON, Alexandre. Neutralité et appartenance au Corps helvétique: Neuchâtel à l'épreuve de la guerre de dix ans. In: CHANET, Jean-François; WINDLER, Christian (coord.). Les ressources des faibles: neutralités, sauvegardes et accommodements en temps de guerre $\mathrm{XVI}^{\mathrm{e}}-\mathrm{XVIII}{ }^{\mathrm{e}}$ siècle. Rennes: Presses Universitaires de Rennes, 2009. p. 63-82.

DUCHHARDT, Heinz. From the Peace of Westphalia to the Congress of Vienna. In: FASSBENDER, Bardo; PETERS, Anne. The Oxford handbook of the history of international law. Oxford: Oxford University Press, Nov. 2012. p. 628-653.

FERGUSON, Niall. Império: como os Britânicos fizeram o mundo moderno. Tradução de Marcelo Musa Cavallari. São Paulo: Planeta, 2010.

FRÉMEAUX, Jacques. De quoi fut fait l'empire: les guerres coloniales au $\mathrm{XIX}^{\mathrm{e}}$ siècle. Paris: CNRS, 2010.

GUGGENHEIM, Paul. Emer de Vattel et l'étude des relations internationales en Suisse. Genève: Georg \& Cie., 1956. 
JOUANNET, Emmanuelle. Emer de Vattel (1714-1767). In: FASSBENDER, Bardo; PETERS, Anne. The Oxford handbook of the history of international law. Oxford: Oxford University Press, Nov. 2012, p. 1.118-1.121.

JOUANNET, Emmanuelle. Emer de Vattel et l'émergence doctrinale du droit international classique. Paris: Pedone, 1998.

KENT, Neil. A concise history of Sweden. Cambridge: Cambridge University Press, 2010.

KINTZLER, Catherine. Condorcet: 1'instruction publique et la naissance du citoyen. $2^{\mathrm{e}}$ éd. Paris: Gallimard, 1987.

KOOIJMANS, Pieter Hendrik. The doctrine of the legal equality of states: an inquiry into the foundations of international law. Leiden: A. W. Sijthoff, 1964.

LA PRADELLE, Albert Geouffre de. Introduction. In: VATTEL, Emer de. The law of nations or the principles of natural law: applied to the conduct and to the affairs of nations and of sovereigns. Translation of the edition of 1758 by Charles Ghequiere Fenwick, with an introduction by Albert Geouffre de Lapradelle (translated by George D. Gregory). Buffalo: Legal Classics Library, 1993. p. III a LV.

LA PRADELLE, Albert Geouffre de. Maîtres et doctrines du droit des gens. $2^{\mathrm{e}}$ éd. Paris: Les Éditions Internationales, 1950.

LINDQVIST, Herman. A history of Sweden. Translated by Rod Bradbury. Stockholm: Norstedts, 2002.

LOCKE, John. Dois tratados sobre o governo. Tradução de Julio Fischer. 2. ed. São Paulo: Martins Fontes, 2005.

LOCKE, John. Two treatises on government. Cambridge: Cambridge University Press, 1960.

MALLARMÉ, André. Emer de Vattel (1714-1767). In: AVRIL, Pierre; BAILBY, Henri; BARTHÉLEMY, Joseph. Les fondateurs du droit international: ... leurs œuvres: leurs doctrines. Paris: V. Giard \& E. Brière, 1904. p. 481-601.

MANCUSO, Francesco. Emmerich de Vattel. In: DAL RI JR., Arno; VELOSO; Paulo Potiara de Alcântara; LIMA, Lucas Carlos (org.). A formação da ciência do direito internacional. Ijuí: Unijuí, 2014. p. 201-250.

MARSEILLE, Jacques. Empire colonial et capitalisme français: histoire d'un divorce. Paris: Albin Michel, 2005.

MARTENS, Georg Friedrich von. Précis du droit des gens moderne de l'Europe: fondé sur les traités et l'usage. 3. ed. Göttingen: Librairie de Dietrich, 1821.

MOSER, Johann Jacob. Erste Grundlehren des jetzigen Europäischen Völkerrechts, in Friends- und Kriegs-Zeiten. Nümberg: Raspe, 1778. 
MUIR-WATT, Horatia. Droit naturel et souveraineté de l'état dans la doctrine de Vattel. Archives de Philosophie du Droit, Paris, v. 32, p. 71-83, 1987.

NEMO, Philippe. Histoire des idées politiques aux temps modernes et contemporains. 1. ed. Paris: PUF, 2002.

OMPTEDA, Dietrich Heinrich Ludwig von. Literatur des gesamten natürlichen und positiven Völkerrechts. Aalen: Scientia Verlag, 1963.

ONUMA, Yasuaki (ed.). A normative approach to war: peace, war, and justice in Hugo Grotius. Oxford: Clarendon Press, 1993a.

ONUMA, Yasuaki. Eurocentrism in the history of international law. In: ONUMA, Yasuaki. $A$ normative approach to war: peace, war, and justice in Hugo Grotius. Oxford: Clarendon Press, 1993b. p. 371-386.

REUTER, Paul. Institutions internationales. Paris: PUF, 1955.

ROELOFSEN, Cornelis Gerrit. International arbitration and courts. In: FASSBENDER, Bardo; PETERS, Anne (ed.). The Oxford handbook of the history of international law. ed. by Oxford: Oxford Univ. Press, 2012. Chap. 6, p. 145-169.

SANDOZ, Yves. (ed.). Réflexions sur l'impact, le rayonnement et l'actualité du 'droit des gens' d'Emer de Vattel. Bruxelles: Bruylant, 2010.

SCELLE, Georges. Manuel élémentaire de droit international public. 2. ed. Paris: DomatMontchrestien, 1948.

SCOTT, James Brown. Le principe de l'égalité juridique dans les rapports internationaux. Recueil des cours de l'Académie de droit international de La Haye, Paris, v. 42, p. 467-630, 1932.

TRUYOL Y SERRA, Antonio. Histoire du droit international public. Paris: Economica, 1995.

TSCHARNER, Benedict von. Inter gentes: statesmen, diplomats, political thinkers. Translation Natasha Proietto. Pregny-Genebra: Édition de Penthes, 2012.

TURGOT, Anne Robert Jacques. Discours: sur les progrès successifs de l'esprit humain (prononcé le 11 décembre 1750). Institut Coppet, juin 25, 2016. Disponível em: https://www.institutcoppet. org/turgot-discours-sur-les-progres-successifs-de-lesprit-humain-1750/.

VATTEL, Emer de. Amusements de littérature, de morale et de politique. Paris: La Haye, 1765.

VATTEL, Emer de. Défense du système Leibnitien contre les objections et les imputations de M. de Crousaz. Leiden: [s. n.], 1741.

VATTEL, Emer de. Dissertation sur cette question: si la loi naturelle peut porter la société à sa perfection, sans le secours des lois politiques. In: VATTEL, Emer de. Le loisir philosophique, on pièces diverses de philosophie, de morale et d'amusement. Dresden: Chez George Conrad Walther, Libraire Du Roi, 1747a. p. 71-94. 
VATTEL, Emer de. Essai sur le fondement du droit naturel, et sur le premier principe de l'obligation où se trouvent les hommes d'en observer les lois. In: VATTEL, Emer de. Le loisir philosophique, on pièces diverses de philosophie, de morale et d'amusement. Dresden: Chez George Conrad Walther, Libraire Du Roi, 1747b. p. 3-70.

VATTEL, Emer de. Guerre littéraire ou choix de quelques polémiques. [S. l: s. n.], 1759.

VATTEL, Emer de. Le droit des gens: ou principes de la loi naturelle, appliqués à la conduite et aux affaires des nations et des souverains. Neuchâtel: Journal Helvétique, 1758. 3 tomes.

VATTEL, Emer de. Le loisir philosophique, on pièces diverses de philosophie, de morale et d'amusement. Dresden: Chez George Conrad Walther, Libraire Du Roi, 1747c.

VATTEL, Emer de. Mélanges de littérature, de morale et de politique. Neuchâtel: [s. n.], 1760.

VATTEL, Emer de. O direito das gentes. Prefácio e tradução: Vicente Marotta Rangel. Brasília: Ed. UnB/IPRI, 2004. Disponível em: http://funag.gov.br/biblioteca/download/0261-direito_das_gentes. pdf.

VATTEL, Emer de. Projet pour la composition d'un elixir des livres, avec diverses lettres à ce sujet. In: VATTEL, Emer de. Le loisir philosophique, on pièces diverses de philosophie, de morale et d'amusement. Dresden: Chez George Conrad Walther, Libraire Du Roi, 1747d.

VATTEL, Emer de. Questions de droit naturel, et observations sur le traité du droit de la nature de M. le Baron de Wolff. Lyon: Berne, 1762.

VATTEL, Emer de. The law of nations, or the principles of natural law: applied to the conduct and to the affairs of nations and of sovereigns. Translation of the edition of 1758 by Charles G. Fenwick, with an intr. by Albert de Lapradelle. Omaha: Legal Classics Library, 1993.

WESSELING, Henri. Les empires coloniaux européens 1815-1919. Traduit du néerlandais par Patrick Grilli. Paris: Gallimard, 2009.

WHITAKER, Urban George. Politics and power: a text in international law. New York: Harper \& Row, 1964. 
